\title{
When Both Utterances and Appearances are Deceptive: Deception in Multimodal Film Narrative
}

\author{
Marta Dynel
}

\section{Introduction}

Despite the prevalence of deception in film, ${ }^{1}$ there is very little rigorous research on this topic in the fields of philosophy and pragmatics. Paying little heed to the characteristics of deception in film discourse per se, some philosophical scholarship on deception is illustrated with verbal examples taken from fiction, presented as specimens of scripted but natural discourse (Dynel, 2016, 2018; see also Vincent Marrelli, 2004). Apart from a few mentions and/or very brief discussions of famous deceptive scenes in film studies (Bordwell, 1985; Chatman, 1978, 1990; Kozloff, 1988), and a range of stylistic content analyses of deceptive characters in fiction, mainly in literature but also in film (e.g. DePaulo, 2010; Ferenz, 2008; Sorlin, 2016), the precious few works in film studies offer more extensive analyses of the phenomenon at hand, albeit variously labelled (e.g. Anderson, 2010; Elsaesser, 2009; Klecker, 2013; Laass, 2008). The topic of deception in literary and film fiction is also tacitly related to the notion of unreliable narration examined in narrative studies (e.g. Anderson, 2010; Burgoyne, 1990; Koch, 2011; Stühring, 2011; Zipfel, 2011). All of these works will be critically addressed in the course of this paper.

The prime aim of this article is to intertwine the relevant research threads and address the gap in philosophical pragmatics by giving a comprehensive theoretical

\footnotetext{
1 "Film" is here used as a technical term for both feature films, and television series/serials (see Dynel, 2011a). It is also used as shorthand for fictional productions (as opposed to documentaries).
}

\author{
M. Dynel $(\bowtie)$ \\ University of Łódź, Łódź, Poland \\ Vilnius Gediminas Technical University, Vilnius, Lithuania \\ e-mail: marta.dynel@yahoo.com; https://orcid.org/0000-0003-4647-946X
}

(C) The Author(s) 2021

F. Macagno, A. Capone (eds.), Inquiries in Philosophical Pragmatics, Perspectives in Pragmatics, Philosophy \& Psychology 28,

https://doi.org/10.1007/978-3-030-56696-8_12 
account of deception in multimodal film narratives, focusing on its general characteristics and workings, as well as its specific types. In order to meet this goal, the present paper brings together a few disciplines and approaches: the pragmatics of film discourse, the cognitive philosophy of film, multimodal analysis, narrative studies and - last but not least - the philosophy of deception. Thereby, it will be shown that, similar to utterances and simple non-verbal (e.g. gesture-based) messages, complex multimodal communications (dependent on various cinematic strategies) are amenable to pragma-philosophical analysis as vehicles for deception in film.

This paper is organised into eight sections. Following this introduction, the section entitled "Film as a Multimodal Narrative Constructed by the Cinematic Narrator" gives an introduction to film as a multimodal narrative, focusing on the notion of the cinematic narrator, and on multimodal transcription and analysis. "Film Cognition" presents a brief overview of film cognition, taking into account the pragmatics of film construction (notably, the two communicative levels). A range of philosophical observations on viewers' cognition of fictional worlds are summarised, with special attention being paid to the notion of make beliefs. The section "Narrative Unreliability" concerns the topical issue, which - as is argued is intimately connected with deception in fiction. This is the topic of "Accounting for Types of Deception and Deception in Film", which critically addresses previous discussions of select types of film deception and, prior to this, gives the gist of deception and its main types investigated in pragma-philosophical literature. In "Types of Multimodal Deception in Film", three main types of film deception are proposed in reference to the two levels of communication on which it materialises, the characters' level and the recipient's level, as well as the narrating performer of the deception, the intradiegetic and/or the extradiegetic narrator. This discussion is illustrated with multimodally transcribed examples of deception extracted from the American television series House. The section "Can the Cinematic Narrator Lie or Just Deceive Otherwise?" attempts to answer the thorny question of whether or not the extradiegetic (cinematic) narrator can lie or only perform other forms of deception. The paper closes with "Conclusions and Final Comments".

\section{Film as a Multimodal Narrative Constructed by the Cinematic Narrator}

Films can be conceptualised as multi-modal narratives (e.g. Bateman \& Schmidt, 2011; Wildfeuer, 2014). Examined originally in literary studies, narration has been a research topic in film studies for a few decades now (e.g. Bordwell, 1985; Branigan, 1984, 2013; Chatman, 1978, 1990; Forceville, 2002; Lothe, 2000; Phillips, 2000; Wildfeuer, 2014). Film scholars frequently focus on the narrative, paying little attention to the narrator. This is because the persona of the narrator, i.e. a perceptible personal/figural narrator (cf. Köppe \& Kindt, 2011), is only intermittent in films (see e.g. Stam, Burgoyne, \& Flitterman-Lewis, 1992). Only sometimes 
are personal narrators present in films (a) on the (intra)diegetic (cf. Genette 1980 [1972]) level as on-screen character narrators, or (b) on the extradiegetic (cf. Genette 1980 [1972]) level as voiceover narrators, whether characters or not. The latter case coincides with what Bordwell (2008) refers to as the Voice of God narrator.

There is an ongoing debate on whether film, or narrative fiction in general, ${ }^{2}$ must involve the extradiegetic/heterodiegetic narrator "as the illocutionary source or instance of emission of the narrative discourse" (Burgoyne, 1990: 4). According to one view, film intrinsically involves an impersonal multimodal narrator (cf. Burgoyne, 1990) that is "external to (not part of) any diegesis" (Prince, 1987: 29) and entirely responsible for the presentation of the diegetic world. This extradiegetic narrator in film narrative has been labelled previously: le grande imagier (Metz, 1974), the camera-narrator (Kozloff, 1988), the intrinsic narrator (Black, 1986), the fundamental narrator (Gaudreault, 1987) or the cinematic narrator (Anderson, 2010; Burgoyne, 1990; Chatman, 1990; Stam et al., 1992). This last term is preferred here, serving as a shorthand metaphor. A view is endorsed here that if there is a narrative, there must be a type of impersonal heterodiegetic narrator involved as a matter of logical necessity (Chatman, 1990; Kozloff, 1988; Ryan, 1981). In addition, the heterogeneous impersonal narrator facilitates establishing the "hierarchy of narrative voices structuring the narrative film" (Burgoyne, 1990: 6).

Bordwell (1985: 62) famously questions this kind of a narrator in film, based on the fact that the viewer is "seldom aware of being told something by an entity resembling a human being," and states that film narration is "the organization of a set of cues for the construction of a story." Although Bordwell (2008: 121-122) later does acknowledge that the narrator in literary works may be non-human/impersonal, which is a widely recognised fact (e.g. Ryan, 1981), he is adamant that this narrative voice is an otiose "personification of the narrative dynamics in film" as it is rarely explicit and can seldom be identified, while the relevant recognised agent is the filmmakers. Bordwell (2008) also presents the notion of a narrator in film as not appealing to any "psychological activity". Whilst this last critical observation seems correct, little support can be given to his explanation that viewers attribute the narrative or some effect to the film itself or the filmmakers, unlike readers who may identify the speaking voice in the narrator or the novel writer. In any case, these claims are nothing but speculative, to put it mildly, and they are not compatible with what many cognitive philosophers of fiction have proposed (see "Film Cognition").

Most importantly, Bordwell's $(1985,2008)$ argument concerning narrator-less film seems to be based on the assumption that a narrator is part of the viewer's cog-

\footnotetext{
${ }^{2}$ Many (Hamburger, 1957; Banfield, 1978; Branigan, 1984; Köppe \& Kindt, 2011; see Sternberg \& Yacobi, 2015 and references therein) claim that the narrator may be absent in literary fiction altogether and the reader is invited to imagine that something is the case without any intermediary telling the story. However, others (e.g. Doležel, 1980; Ryan, 1981) argue this intermediary, albeit not necessarily anthropomorphic, is a must, tacitly representing the real author in a given work. On some accounts, the presence of this narrator is what makes extradiegetic deception possible, for it prevents the author from shouldering the blame for it (see "Can the Cinematic Narrator Lie or Just Deceive Otherwise?").
} 
nitive reality, i.e. that the viewer needs to be aware of the narrator (see also Branigan, 1984). However, as Ryan convincingly puts it, "the concept of narrator is a logical necessity of all fictions, but it has no psychological foundation in the impersonal case. This means that there is no need for the reader of impersonal narrations to seek an answer to the question "who speaks?"' (1981: 519). The viewer will not typically ask this question also because their focus is strictly on the fictional world, rather than the medium or the actual author, i.e. production crew, contrary to what Bordwell (2008) contends (see "Film Cognition"). Hence, the cinematic narrator should be seen as an empirically validated construct; rather, it is a theoretical and abstract notion that facilitates philosophical discussion. Burgoyne neatly summarises this issue: "In creating the fictional world, the impersonal narrator produces a type of discourse that is read directly as the facts of the 'real world' of the fictional universe. The impersonal narrator's lack of human personality allows the viewer to imagine that he or she is confronting the fictional universe directly, putting aside any reflection on the form of the narrative discourse" (1990: 7). This kind of narrator bears some resemblance to the impersonal narrator in literary fiction regarded as being, at least partly, "covert", "backgrounded" or "non-perceptible" (see e.g. Chatman, 1978; Ryan, 1981; Toolan 2001 [1988]; Bal 1997 [1992]). Even though this narrator is usually not to be consciously recognised by the recipient, i.e. the model viewer (Dynel, 2011a, b), it does constitute the lens through which the recipient perceives select elements of the fictional world. ${ }^{3}$ Importantly, the cinematic narrator is, in fact, the product of the collective sender (see Dynel, 2011a, b), a technical term for the film production crew responsible for the creation of the multimodal narrative.

Multimodality is also a heterogeneous notion that escapes easy definitions. Despite numerous attempts (e.g. Elleström, 2010; Jewitt, 2009; Kress, 2010), there is no unanimous agreement on how modes or modalities should be defined (Forceville, 2010). It is, nonetheless, commonly held that multimodality involves multiple integration of semiotic resources (Baldry \& Thibault, 2006; Kress, 2010). Suffice it to say that films are multimodal products insofar as they encompass characters' utterances and non-verbal messages (facial expressions and body language), as well as actions; written language; sounds, music and lyrics; and - last but not least - visuals, which depend on various cinematic components (e.g. continuity editing). This multimodality encompasses both film discourse, i.e. characters' verbal interactions (see Dynel, 2011a, b, for discussion and alternative terms), and cinematic discourse, which encompasses the various forms of "communication not in film but through it (cf. Metz, 1974)", such as "mise-en-scène, cinematography, montage, and sound editing used in narrating cinematic stories to viewers" (Janney, 2012: 85). Both conventionalised and novel cinematic strategies (for an excellent overview, see Bordwell and Thompson 2013 [1979]) are carriers of explicit and implicit meanings relayed to viewers.

\footnotetext{
${ }^{3}$ Presumably, the proponents of the fiction-without-narrator view would still argue that this film narrator is actually absent since we are not asked "to imagine anything about a fictional narrator" (Köppe \& Kindt, 2011: 84).
} 
Operating across different modes, both film discourse and the whole gamut of cinematic components perform the narrative function (cf. Kozloff, 2000) and affect viewers' interpretation of the goings-on on screen (Wildfeuer, 2014). Hence, the recipient reconstructs the story in the fictional world, based on the multimodal narrative, i.e. the story's material representation which "consists of material signs, the discourse, which convey a certain meaning (or content)" (Ryan, 2007: 24). According to Bordwell, film narration is "the process by which the film prompts the viewer to construct the ongoing fabula [i.e. the events, as represented, cf. Genette 1980 (1972)] on the basis of syuzhet organization and stylistic patterning" (2008: 98). This necessitates viewers' active participation, inferences and sense-making. For instance, "[w] hen information is missing, perceivers infer it or make guesses about it. When events are arranged out of temporal order, perceivers try to put those events in sequence" (Bordwell, 1985: 33f.).

\section{Multimodal Analysis}

The joint use and interplay of different elements from various semiotic resources across modalities require that they be investigated jointly, as stipulated by Baldry and Thibault's (2006) resource integration principle. The different semiotic resources "are combined and integrated to form a complex whole which cannot be reduced to or explained in terms of the mere sum of its separate parts" (Baldry \& Thibault, 2006: 18). In "Types of Multimodal Deception in Film", select scenes from the American televisions series House will be transcribed in order to exemplify film communication processes and to present what the recipient is exposed to when an act of film deception is performed. An adapted version of Baldry and Thibault's (2006) multimodal transcription toolkit will facilitate the description of the meaning-making resources across modes, and hence promote viewer's understanding and (make) belief making about the fictional world (see "Film Cognition"). As Forceville (2007) aptly observes, Baldry and Thibault's (2006) toolkit can benefit from film terminology known from various sources, such as Bordwell and Thomson's (2013 [1979]) oft-quoted and continually revised magnum opus. In line with what Forceville (2007) suggests, clusters of variables within and across modes are included in the transcriptions. For the sake of clarity, the transcription is restricted to the most salient elements that are central to the recipient's meaning-making (Baldry \& Thibault, 2006: 183) in order to best depict the multimodal construction of various types of deception operating within and across scenes.

A scene, here involving an act of deception, can be divided into the key multimodal analytic units, namely phases. These are sets of "copatterned semiotic selections that are codeployed in a consistent way over a given stretch" of discourse (Baldry \& Thibault, 2006: 47; Martinec, 1998). A phase is a carrier of the central meaning and often comprises more than one shot, i.e. a filmed sequence without the camera's spatial displacement. As Baldry and Thibault observe, a multimodal text analyst needs "to specify both which selections are selected (sic) from which 
semiotic modalities and how they are combined to produce a given, phase-specific meaning" (2006: 47). The transcription tables in the analyses conducted here are organised as follows:

- Column 1 number and name/meaning of the phase

- Column 2 the lead-in time starting from the beginning of the scene (Example 1) or the episode (Examples 2 and 3)

- Column 3 select pivotal frames, i.e. stills in chronological order

- Column 4 elements of cinematography (e.g. distance or camera position) and mise-en-scène (e.g. location or characters' kinetic action)

- Column 5 diegetic and non-diegetic soundtrack (e.g. dialogues, voice-over or music score)

As also pointed out by Baldry and Thibault (2006), the transcription and analysis of the multimodal discourse must be performed from an etic perspective. The aim is to depict the (ideal) model of the interpretation process and to account for the deceptive meanings the collective sender will intend the recipient to glean about the fictional world.

\section{Film Cognition}

In linguistic terms, film operates on two levels of communication, which have been captured by two spatial metaphors: "The first one understands fictional interaction as embedded in communication between authors/producers and audiences; the second one places inter-character talk on a layer on top of the primary layer between the producers and recipients of the artefact" (Messerli, 2017: 33). Essentially, many authors (e.g. Bubel, 2008; Dynel, 2011a; Kozloff, 2000; Piazza, Bednarek, \& Rossi, 2011 and references therein) underscore the simple fact that the characters' interactions (here called the characters' level of communication), as shown on screen, depend on what the film production crew (i.e. the collective sender) wants to communicate to the audience on the recipient's level of communication with the use of a wide range of multimodal (cinematic and discursive) strategies. The characters' level of communication constitutes what is known in narratology and the philosophy of fiction as the fictional world, ${ }^{4}$ i.e. the diegesis (Genette 1980 [1972], see e.g. Daugherty, 2007), which is constructed for the recipient to follow. ${ }^{5}$

The collective sender can "organize the film so as to solicit a range of effects", but "the viewer has a freedom to seize upon certain cues and not others" and use

\footnotetext{
${ }^{4}$ This world shows many overlaps with the real world and is the point of departure for the recipient engaged in sense-making (see e.g. Doležel, 1998; Lamarque, 1996; Lewis, 1978; Margolin, 1992; Ronen, 1994; Ryan, 1980).

${ }^{5}$ If the production crew should make mistakes (for instance, in the script, camera work or editing), the viewers may be (inadvertently) misled, but not (purposefully) deceived about the fictional world, developing some false beliefs about it.
} 
them "in ways that couldn't be foreseen by the filmmakers. (...) Cinematic traditions, however, secure a considerable amount of convergence between what filmmakers know can affect viewers and what viewers do experience" (Bordwell 2008: 123). The preferred inferential path and understandings projected by the production crew for the model viewer (here, the recipient), may then differ from actual viewers' actual interpretations (see Bordwell, 1985; Persson, 2003; Stafford, 2007) depending on their life experiences, values, and beliefs social background, preferences, cognitive abilities, etc. (e.g. Morley, 1980; Phillips, 2000; Wharton \& Grant, 2005). This problematising aside, the focus of this paper is film deception as designed by the collective sender for the recipient, the model viewer who does follow the projected inferential paths and is indeed deceived. Deception is then one of the effects in film that rely on "convergent inference making. The filmmaker has gotten us to walk down the path she planned" (Bordwell 2008: 124).

Prototypically, the recipient of a fiction film focuses on the characters' level of communication, which means basically the fictional world depicted in the diegesis, without consciously appreciating the production crew's work, ${ }^{6}$ and even forgetting that he/she is engaged in the act of watching a film (see Dynel, 2011a, b). Films encourage the Coleridgean willing suspension of disbelief (Bordwell, 1985; Ryan, 2001), and "sustain the illusion that the viewer is observing the action as a fly on the wall" (Kozloff, 2000: 47), being judged based on how "well they transport us into the worlds of the stories. If an adventure story is good, we imagine its world so vividly that it is like a movie running off in our heads" (Clark, 1996: 366). Hence, while it is the collective sender that communicates meanings to the recipient, the latter does not consciously see the meanings as being produced by the former unless purposefully choosing to do so (as film critics and scholars do) or unless the collective sender invites the recipient to consider their intentions (e.g. in complex metaphors) or manifestly shatters the diegesis with their cinematic methods (e.g. breaking the fourth wall).

This line of reasoning corresponds to a number of postulates made in the philosophy of fiction about film watching. It has been proposed that this is an act of joint pretence (see Clark, 1996; Clark \& Van Der Wege, 2001; Walton, 1990). Viewers thus forget that they are interpreting fictional interactions and events as if they are actually taking place in front of them, and they let themselves be captivated by the fictional world. This is known, among other things, as transportation (e.g. Gerrig, 1993; Green \& Brock, 2000, 2002) or immersion (Ryan, 2001). As Ryan (2001: 14) observes, "immersion is the experience through which a fictional world acquires the presence of an autonomous, language-independent reality populated with live human beings." A pending query is what mental states recipients have with regard to these fictional worlds.

It may be claimed that one of the primary goals of films "is to make it compelling for us to believe in their implied [fictional] worlds for the duration of any screening

\footnotetext{
${ }^{6}$ This does not seem to hold for non-mainstream, highbrow films rich in metaphors or symbols, or genres such as sitcom comedies, where the "code of realism" is broken.
} 
(and, in our private reflections, for any time thereafter)" (Murphet, 2005: 52, emphasis added). However, it is most often stated that recipients only imagine (Currie, 1995; Currie \& Ichino, 2013) or make believe (for different conceptualisations, see Lewis, 1978; Currie, 1990; Walton, 1990; Lamarque, 1996; Ryan, 2001; Sainsbury, 2009) that something is the case in a fictional world. Therefore, rather than having genuine beliefs per se, film viewers can only have pretend beliefs (Nichols and Stich 2003). Similarly, employing formal belief revision theory, Badura and Berto (2018) conceptualise beliefs based on fiction as make believed beliefs. According to Nichols and Stich (2003), genuine and pretend beliefs are very much alike in practice but differ mainly in their functional roles. Also, cognitive processes can take input from the "pretence box and from the belief box", forming "parallel representations much the same way" (Nichols \& Stich, 2003: 131). Despite the striking similarities between the two belief categories, viewers' understandings of the fictional world cannot be technically labelled "beliefs" per se, as many authors assert (but see Stühring, 2011 on beliefs about the fictional world) ${ }^{7}$; these are rather pretend beliefs, make believed beliefs or simply make beliefs. This last label is preferred here. Thus, recipients develop make beliefs about the fictional world, i.e. what they make believe to be true in/about the fictional world. As will be shown here, these make beliefs may be false, as intended by the collective sender. In other words, the recipient of fiction, notably a model film viewer, can develop false make beliefs about the fictional world at hand, hence being deceived, or technically make believe deceived, about its make believe/fictional truth.

The truth and, by analogy, falsity, as well as make beliefs about both are relative to the fictional world considered, and the "fictional facts" therein (see Badura \& Berto, 2018; Lewis, 1978; Sainsbury, 2009; Stühring, 2011). Within a fictional universe "truth is not determined relative to an extratextual universe, but relative to a fictional world" (Ronen, 1994: 40). Fictional worlds, however, involve not only fictional facts but also nonfactual elements, such as a character's beliefs, desires or predictions (Doležel, 1980; Ronen, 1994). Thus, the objective world of the text, comprised of facts in fiction, does not exclude characters' private, subjective domains defined as pretended worlds the characters create to deceive other ones, as well as their minds' fabrications, such as hallucinations, fantasies and dreams (Ryan, 1991). The "truth of the text," and "the reliability of characters purporting to speak that truth, can be measured only against the authentic facts of the fictional universe" (Burgoyne, 1990: 10). Overall, just like the real world has its objective but frequently, non-verifiable - truth, each fictional world has its own fictional truth (Walton, 1990; Margolin, 1992; Zipfel, 2011; cf. Lewis, 1978), based on the narrator's make believe truthfulness. The make believe truth of the fictional world is what "readers [or viewers] can reasonably assume to be an existing state of affairs in a fictional world or, in other words, what readers [or viewers] are authorized to believe to be an existing state of affairs in a fictional world according to the [multimodal]

\footnotetext{
${ }^{7}$ Make beliefs about fictional worlds should not be mistaken for genuine beliefs that films can also inspire in viewers (e.g. regarding moral choices or political opinions).
} 
text" (Zipfel, 2011: 110), based on the presumption of truthfulness for fiction (Lamarque, 1996), a mirror reflection of the same principle holding for real-life communication (e.g. Bok, 1978; Kupfer, 1982).

It is noteworthy that the relevant aspects of the make believe truth of the fictional word are often easier to determine without a shadow of a doubt than the truth of the real world. Participating in all interactions and events shown on screen, the viewer usually enjoys the necessary knowledge about all pertinent fictional facts. This is because the collective sender needs to guarantee that the recipient has access to the relevant aspects of the fictional truth and develops "correct" make beliefs about the fictional world, unless make beliefs are meant to be "wrong", precisely false. The latter situation means that the collective sender aims to deceive the recipient about some aspect of the fictional truth of the fictional world, as designed by the former. As will be argued here, this deception may be performed with or without the use of deceptive fictional characters, who have their fictional intentions and beliefs about their fictional world. Albeit carried out in the real world by the collective sender, deception of the recipient about the fictional world is anchored in the latter's developing, not false beliefs, but rather false make beliefs, namely the specific beliefs about the fictional truth (e.g. Zipfel, 2011), guided by the cinematic narrator. This is the central topic of the remainder of this article, and it is connected with the notion of narrative unreliability.

\section{Narrative Unreliability}

Narrative unreliability (or unreliable narration) is a literary notion (for an extensive overview, see Sternberg \& Yacobi, 2015). Although it has been most frequently addressed with reference to literary works, it "can be found in a wide range of narratives across the genres, the media, and different disciplines" (Nünning, 2005: 90, cf. the contributions in Nünning, 2015). The concept of narrative unreliability is credited to Booth (1983 [1961], see Olson, 2003; Shen, 2011), who conceived it as a rather eclectic construct. An unreliable narrator is one that "does not act in accordance with the norms of the work" (1983 [1961]: 158). Also, Booth uses the labels "unreliable", "untrustworthy" and "fallible" interchangeably (1983 [1961]: 158). Most importantly, unreliability need not always concern dishonesty and purposeful untruthfulness. There may be various causes of it (see Shen, 2011 for an overview). Thus, only some (but not all) unreliability qualifies as the narrator's deceptive unreliability (Stühring, 2011).

Olson (2003) rightly distinguishes between "fallible" and "untrustworthy" narration, which she presents as gradable notions. Whilst the former can be attributed to the narrator's naiveté, the latter concerns a narrator's being "dispositionally unreliable", being driven by "ingrained behavioral traits or some current self-interest" (Olson, 2003: 102, emphasis in original). This dispositionally unreliable narrator can then be responsible for various forms of deception, including "lies" (Fludernik, 1999). Essentially, unreliable narrators can purposefully report something that is 
false in the fictional world (Badura \& Berto, 2018). However, if the receivers of fiction are not aware of a narrator's (unintended) fallibility, it is also the fallible narrator that may unwittingly invite false make beliefs in readers (and viewers alike), and hence mislead, but not (purposefully) deceive them. It is, however, also in this case that the receiver of a fictional narrative develops false make beliefs about the fictional reality (see "Can the Cinematic Narrator Lie or Just Deceive Otherwise?"). Therefore, all unreliability, as long as the receiver of fiction is not cognisant of it, may serve deceptive purposes, as envisaged by the authors (here, the collective sender).

For their part, Köppe and Kindt (2011: 90) propose that a fictional work is "mimetically unreliable" if it "authorizes imagining that the narrator does not provide completely accurate information" or "authorizes imagining states of affairs that are not completely accurate." Reporting on this definition, Zipfel states that unreliable narration concerns situations when "the narrator does not give completely accurate information, or that the narration is misleading as to what counts as fictional truth" (2011: 117). This lack of (complete) accuracy and the concept of misleading are rather vague notions. The underlying ideas are better captured by "deception", which is the technical blanket term for various ways of inviting false (here, make) beliefs.

Zipfel also addresses narrative unreliability in the context of Grice's Cooperative Principle, especially "with its quality and quantity maxims", stating that it is "not the author who does not organise his communicative contribution according to the Cooperative Principle but the narrator" (2011: 119). Similarly, Heyd (2011: 7) claims that a "narrative is unreliable if it violates the $\mathrm{CP}$ without the intention of an implicature". These statements give rise to several misgivings given the thrust of Grice's (1989) philosophy of communication. Essentially, the Cooperative Principle, the principle of rationality, cannot be violated: implicatures are generated based on the joint assumption that the principle holds, and deception succeeds when both the deceiver and the target of deception operate on the same presumption, the mismatch in their perception of the ongoing communication regardless (see Dynel, 2018 for detailed discussion, cf. Meibauer, 2014). Heyd (2011), however, is right in suggesting that unreliable narratives exploit maxim violations (to which the target of deception is oblivious), which are indeed conducive to various forms of deception, and it always involves the violation of Grice's first maxim of Quality (see Dynel, 2018; Vincent Marrelli, 2004). The pending query is who performs this maxim violation, the narrator or the author; this is the query that the section "Can the Cinematic Narrator Lie or Just Deceive Otherwise?" will address.

Narrative unreliability has been discussed also in film studies (e.g. Chatman, 1978; Burgoyne, 1990; Laass, 2008; Bordwell 2008; Anderson, 2010; Koch, 2011). The proposals therein are of immediate relevance to the present account of film deception which needs to be done in the light of the types of deception discerned by (language) philosophers. 


\section{Accounting for Types of Deception and Deception in Film}

Based on previous definitions (e.g. Bok, 1978; Carson, 2010; Chisholm \& Feehan, 1977; Mahon, 2007), deception (in real-life interactions) may be defined as an intentional communicative act of attempting (whether or not successfully) ${ }^{8}$ to cause the target, i.e. targeted receiver of the believed false message, to (continue to) have a false belief, that is to believe to be true something the deceiver believes to be false (for a detailed explanation, see Dynel, 2018). Deception is then conceptualised with regard to the communicator's beliefs, and more specifically, intentional untruthfulness rather than (objective) falsity (e.g. Aquinas, 1972; Augustine, 1952; Bok, 1978; Dynel, 2018; Fallis, 2010; Mahon, 2015; Meibauer, 2005, 2014; Vincent Marrelli, 2004, 2006). In the present context, the make beliefs about the truth/falsity are relative to the fictional world/reality (cf. Zipfel, 2011) depicted in a given film.

Deception can take a number of forms, the most important of which for the present purposes are: (a) lying, i.e. roughly, making a believed-false covertly untruthful assertion, (b) deceptively implicating defined as saying something truthful but implicating something covertly untruthful through flouting the Gricean maxims, (c) deceptively withholding information, which involves communicating nothing or something truthful and keeping covert an all/part of the believed-true meaning in order to deceive the hearer, (d) covert ambiguity, which relies on two alternative interpretations, with the salient interpretation being the covertly untruthful one, and the hidden meaning - which is not to be discovered by the target - being the truthful one, and (e) covert irrelevance, which rests on providing covertly irrelevant information as if it is relevant to the question under discussion (for a detailed overview and references, see Dynel, 2018, 2019). These (and other) types of deception can be seen through the lens of a neo-Gricean framework of communication. Essentially, all involve (covert) violation of the maxim of truthfulness (the first maxim of Quality), which may be the consequence of violating or flouting another maxim (see Dynel, 2018).

Additionally, deception may be performed in different modes and through different channels: in written or spoken discourse, and verbally and non-verbally, notably via gestures, actions and artefacts (e.g. Bok, 1978; Chisholm \& Feehan, 1977; Ekman, 1985; Linsky, 1963; Mahon, 2007, 2015; Meibauer, 2005; Siegler, 1966; Simpson, 1992; Smith, 2004; Vrij, 2008). Importantly, lies need to involve asserting, but asserting is not restricted to using words in speaking or writing; lies can be told non-verbally as long as a non-verbal signal carries a conventionalised or previously established assertoric meaning (see e.g. Bok, 1978; Chisholm \& Feehan, 1977; Green, 2001; Mahon, 2015), which can be paraphrased verbally. This also

\footnotetext{
${ }^{8}$ It needs to be repeated again that here the focus is on model film deception of the recipient, who is successfully deceived, as envisaged by the collective sender.
} 
pertains to multimodal lies in films. What is submitted here is that all deception may also be performed through multimodal means, transcending the level of non-verbal messages in everyday interpersonal interactions. Films are a case in point.

There is no novelty in the observation that films may involve deception, even though this issue has been hidden under various labels and in various conceptualisations in film studies (see also section "Can the Cinematic Narrator Lie or Just Deceive Otherwise?"). For instance, Bordwell (1985: 39) states that "a film may contain cues and structures that encourage the viewer to make errors of comprehension" conducive to his/her "misunderstanding". However, these alleged inadvertent "errors" or "misunderstandings" are epistemic effects that are purposefully exerted on the recipient by the collective sender with the help of the unreliable cinematic narrator.

For her part, Laass (2008: 43-79) distinguishes between a number of forms of unreliability, and hence deception, on several narrative levels. The first level coincides with what is called here the characters' level of communication, involving deception performed by characters, also narrating previous events. On the second level, Laass (2008) distinguishes unreliable "explicit" voice-over narration, and on the third level, she identifies "implicit" narrative communication, which concerns non-verbal communication (e.g. focalisation or perspectivisation through presenting a character's point of view). Finally, the fourth narrative level concerns textexternal communication. The problem with this approach is that the levels, and the types of unreliability they entail, are not distinct, and the rationale and criteria for the divisions, especially the one between the second and third levels, are rather obscure and confusing (notice also the label "implicit" used in reference to "nonverbal", which are two independent dimensions in linguistics).

It is proposed here that film deception may rely strictly on elaborate multi-modal cinematographic ploys orientated towards deceiving the recipient or it may manifest itself in character's actions and utterances aimed at deceiving other characters. This dichotomy is, presumably, what Klecker (2013: 134) means when she (rather vaguely) states that either "the film itself deceives the audience, or one or more characters do." More specifically, deception in film may arise on the characters' communicative level, where the characters deceive one another in the fictional world, with the recipient being simultaneously deceived too or not (when privy to the act of deception at hand); or solely on the recipient's level, with the only target of deception being the recipient (cf. Dynel, 2013).

Interestingly, in her discussion of mind-tricking narratives, Klecker (2013) claims that deception performed by characters can be divided into two types. She states that either "a character simply lies" (Klecker, 2013: 134), a claim that should be generalised as: a character deceives (by lying or performing any other type of deception); or "characters lie to themselves" (2013: 135), and more broadly "deceive themselves unknowingly" (2013: 136). However, the latter strategy, which is the consequence of characters' mental incapacity (e.g. memory loss or schizophrenia) 
rather than, at least partly, intentional acts can hardly be seen as self-deception in a technical sense (deception is purposeful, and being wrong/deluded has little to do with it). What is crucial is the way the character's mental incapacity is presented by the cinematic narrator; the (only) deception that does arise is targeted solely at the recipient when the cinematic narrator (in accordance with the collective sender's plan) presents the fictional world the way the misguided or incapacitated character perceives it (see also Anderson, 2010; Ferenz, 2008; Koch, 2011), a fact about which the recipient learns only with the benefit of hindsight. ${ }^{9}$ Usually, this perspectivisation is not done through point-of-view shots (see Bordwell and Thompson 2013 [1979]), whereby the camera takes the position where the (deluded) character's eyes would be. The character's "subjectively distorted" perceptions are "presented without external framings or internal markers to distinguish them from shots of fictionally real events" (Koch, 2011: 73). The cinematic narrator deceives by adopting "an unreliable focalizer's point of view as if it were accurate" (Anderson, 2010: 89). Ultimately, the deceived recipient is allowed to recognise that the previous scenes, sometimes amounting to the whole film, have presented the character's warped view of the fictional world.

The thrust of this critique of Klecker's (2013) work is that a character's deception of another character can only be juxtaposed with the cinematic narrator's deception of the recipient, even though the former may also entail the deception of the recipient and does rely on the cinematic narrator too (e.g. in how the deception is shown to the recipient).

Additionally, film deception may be discussed in the context of its time span. Sometimes, film deception may be specific to a single scene and even only part of it. Alternatively, it may span an entire film, echoing across many scenes until the denouement, in various forms and guises, as is the case with films such as Primal Fear, The Machinist or Fight Club. Albeit showing striking differences, these are the films that Elsaesser (2009) calls "mind game films" ${ }^{10}$ and Klecker (2013) dubs "mind-tricking narratives". This temporal distinction corresponds to "temporary"

\footnotetext{
${ }^{9}$ Interestingly, Stühring (2011) vindicates literary narratives that involve "a narrative-persona whose report is wrong or lacking relevant information", stating that they are not deceptive insofar as the work per se "does not justify any wrong beliefs (...) about the fictional facts." This conceptualisation, however, misses the crucial fact that the intradiegetic narrator is actually the product of the author whose aim is to deceive the reader.

${ }^{10}$ However, this seems to be a broad notion that goes beyond deception and covers films that involve "playing games" with characters and/or audiences. Many of the examples of films that Elsaesser (2009) provides do not really involve "disorienting or misleading spectators", which is presented as "one overriding common feature of mind-game films" (Elsaesser, 2009: 15). Nor do they even involve characters' deceiving other characters. Overall, the mind-game film category is rather vague.
} 
vs "sustained" (Currie, 2004; cf. Zipfel, 2011) or "local” vs "global" (Koch, 2011) narrative unreliability.

\section{Types of Multimodal Deception in Film}

The present account of the types of film deception is dictated primarily by the communicative level on which it materialises, namely the characters' level and/or the recipient's level of communication. The former concerns deception performed by characters in the diegetic world, while the latter concerns the manner in which the diegetic world, free from deception per se, is presented to the recipient. These two ways in which deception may be deployed in films (by the collective sender) can be intersected with two types of unreliable narrators, intradiegetic and extradiegetic. The three forms or film deception thus discerned are illustrated with examples of deceptive scenes taken from House and discussed in terms of specific categories of deception examined in philosophical studies.

\section{Extradiegetic Deception Performed Only by the Cinematic Narrator}

The first broad category of film deception targets only the recipient, being performed solely by the cinematic narrator. This deception does not present itself on the characters' level of communication and is, therefore, external to the fictional world per se, which is why it can be conceptualised as extradiegetic deception. It is the collective sender's various multimodal strategies that cause the recipient to develop false make beliefs about the diegetic goings-on in the fictional world. This form of multimodal film deception can be interpreted as a special case of narrative unreliability performed solely and directly by the unreliable cinematic narrator, who - at the service of the collective sender - invites false make beliefs in the recipient. This form of deception underlies the salient category of film that is anchored in the presentation of the key protagonist's warped perception of the fictional reality (e.g. Anderson, 2010; Ferenz, 2008; Klecker, 2013; Koch, 2011; Laass, 2008). However, this focalisation through a misguided or incapacitated character is by no means the only application of this type of deception, as Example 1 illustrates (Fig. 1).

\section{Example 1: Episode 16, Season 7}

[Dr Lisa Cuddy split up with Dr Greg House after he had failed her by missing her cancer tests and by starting to abuse Vicodin again after seemingly successful rehab. Devastated, he engages in frivolous distractions in a hotel room where he is staying, with Dr Wilson, his only friend, checking up on him from time to time.] 


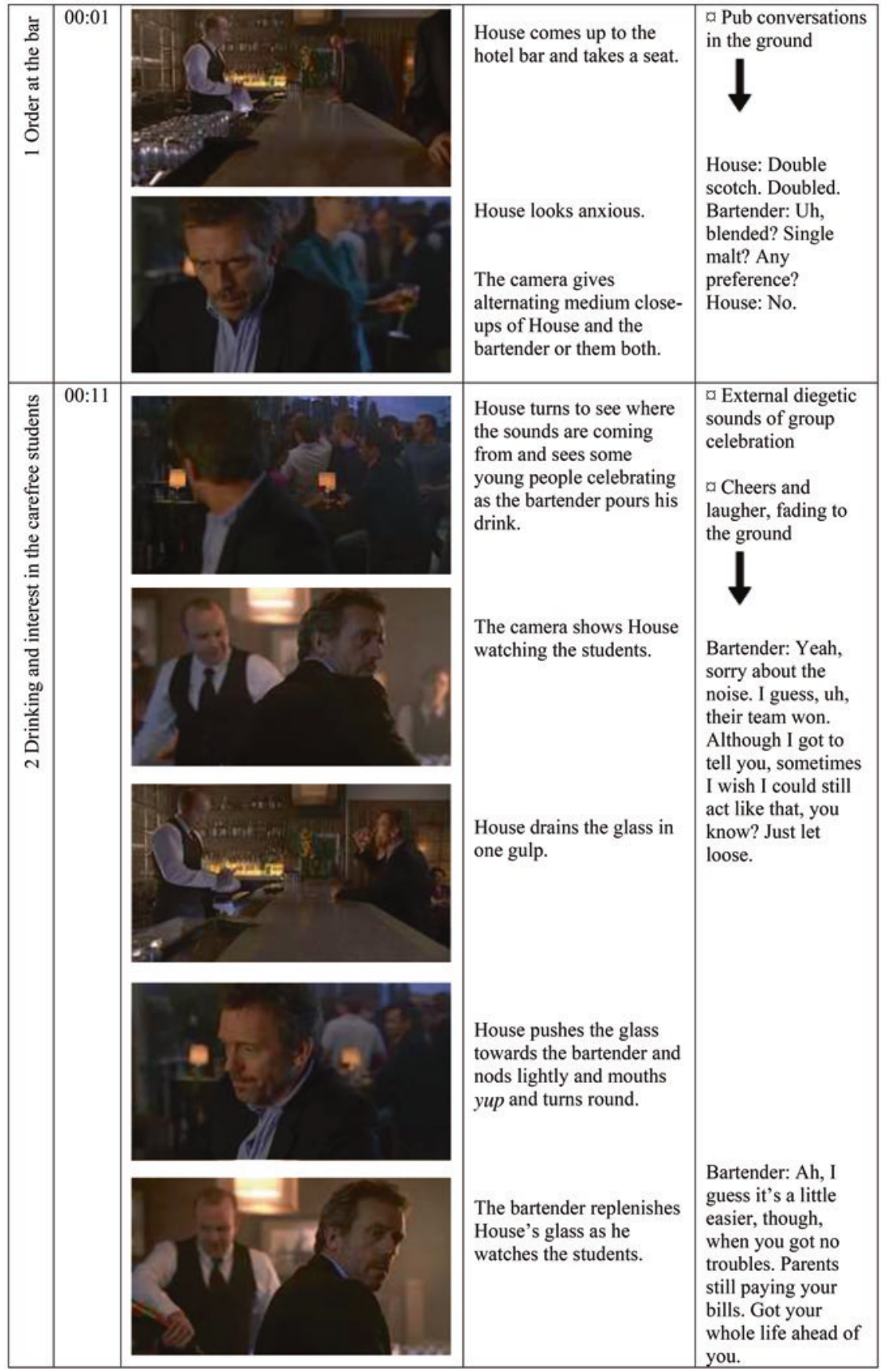




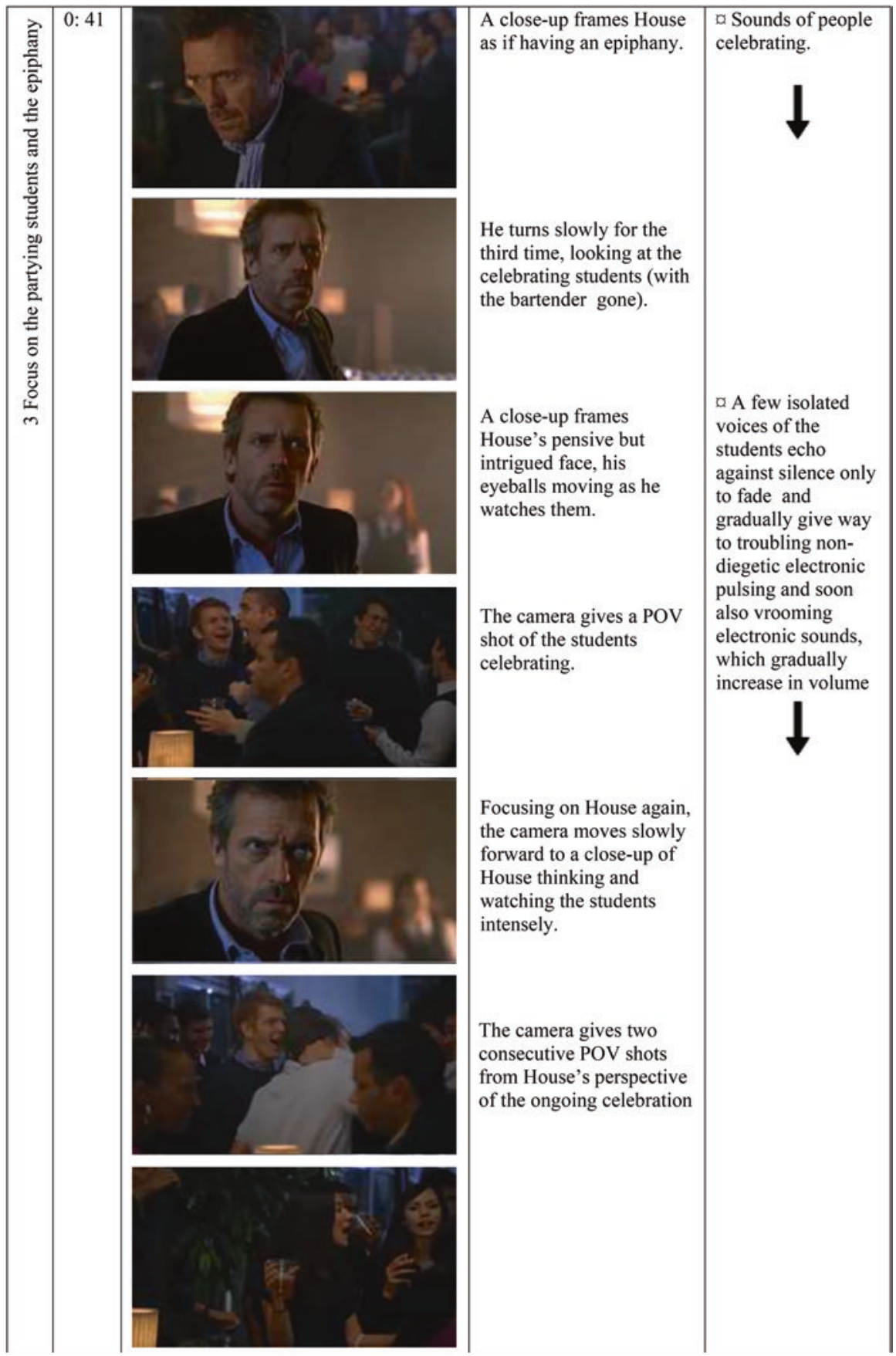




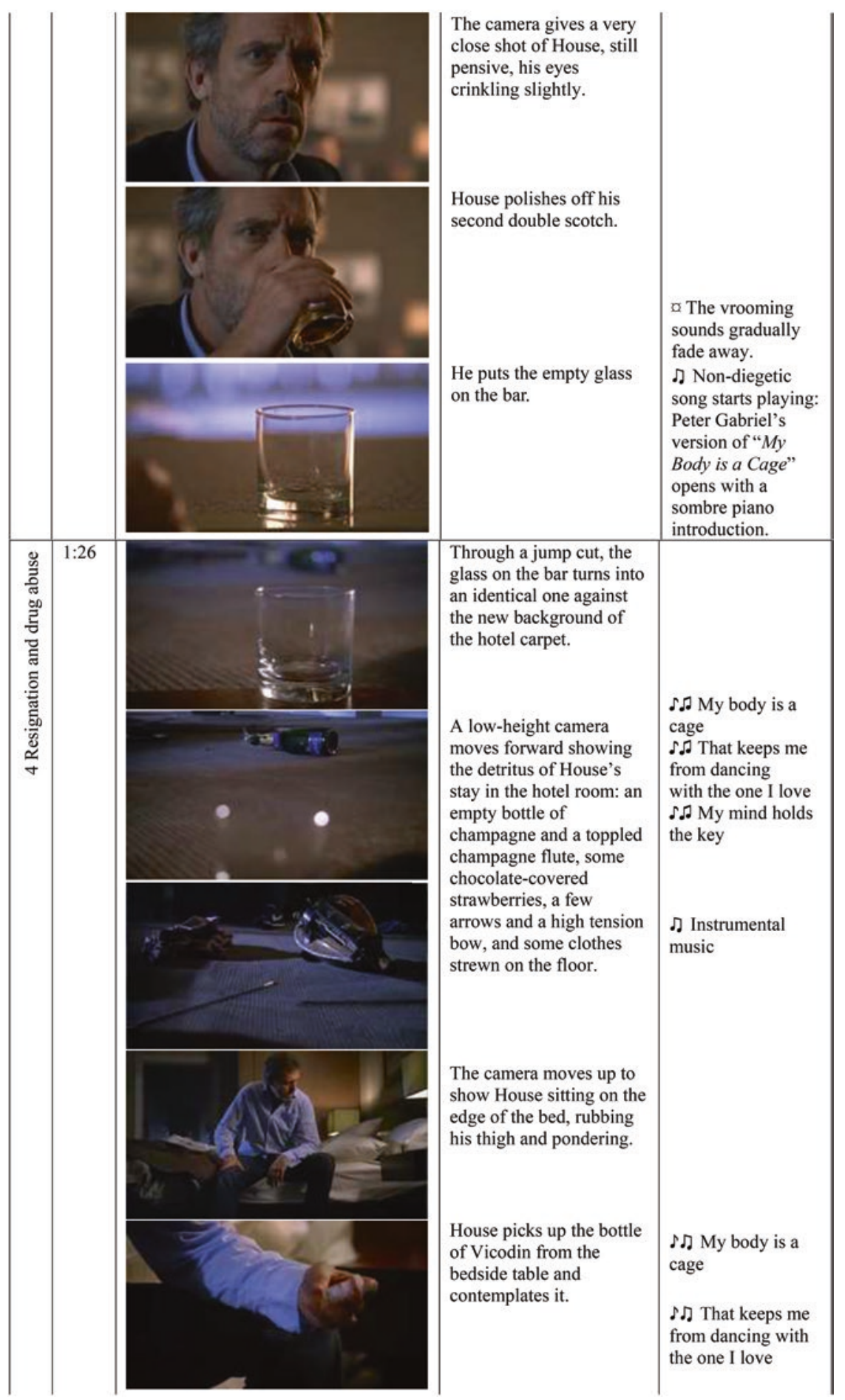




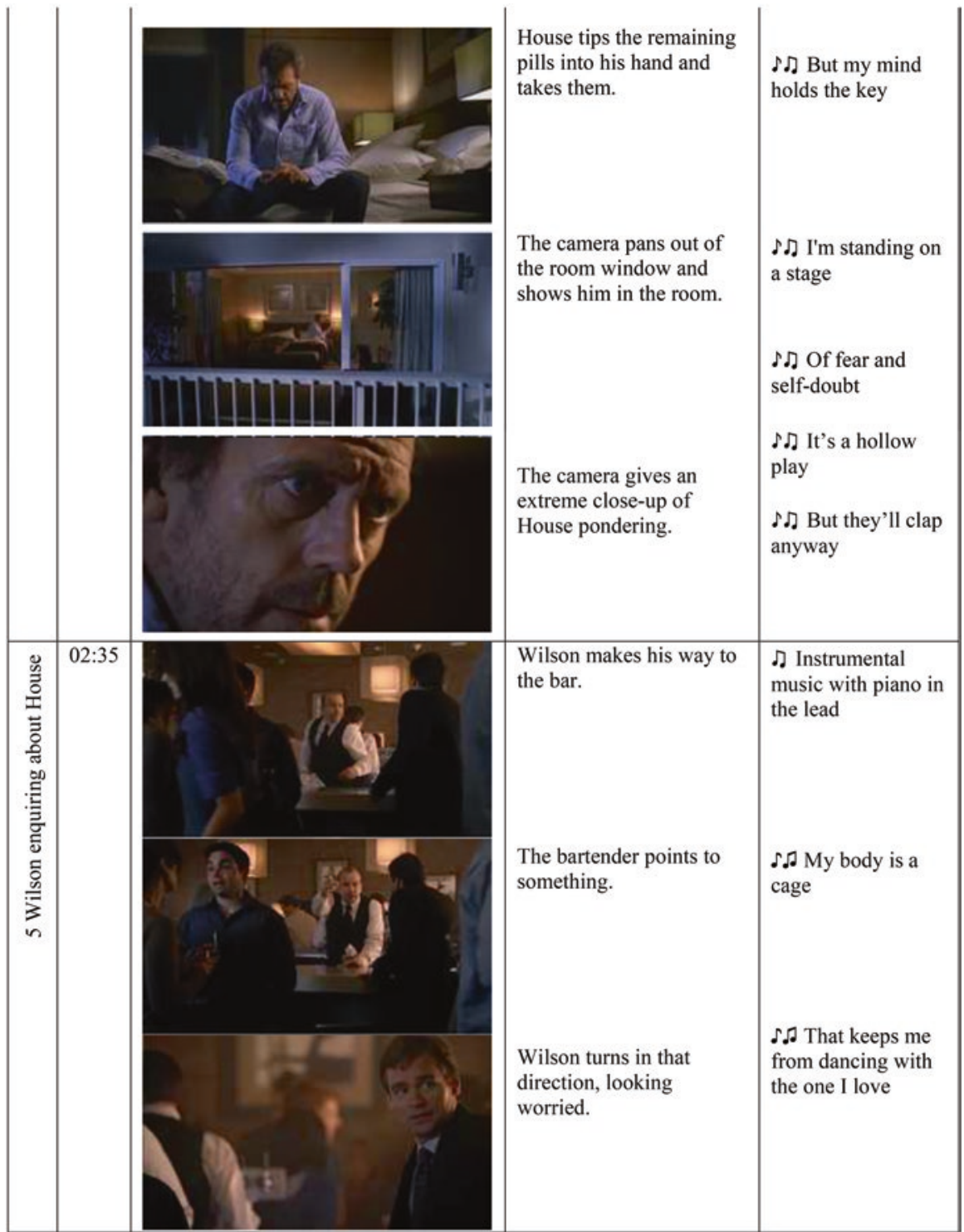




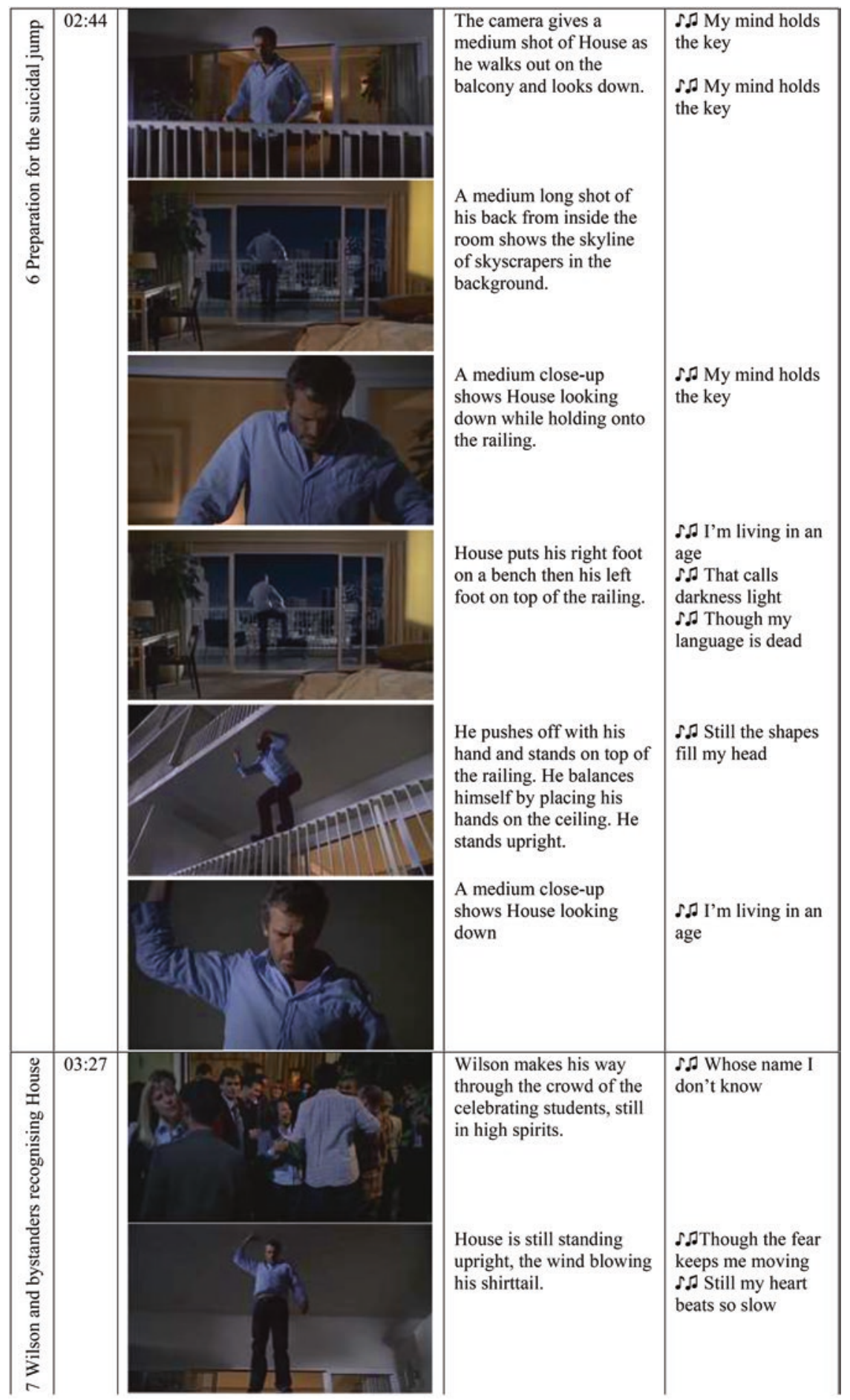




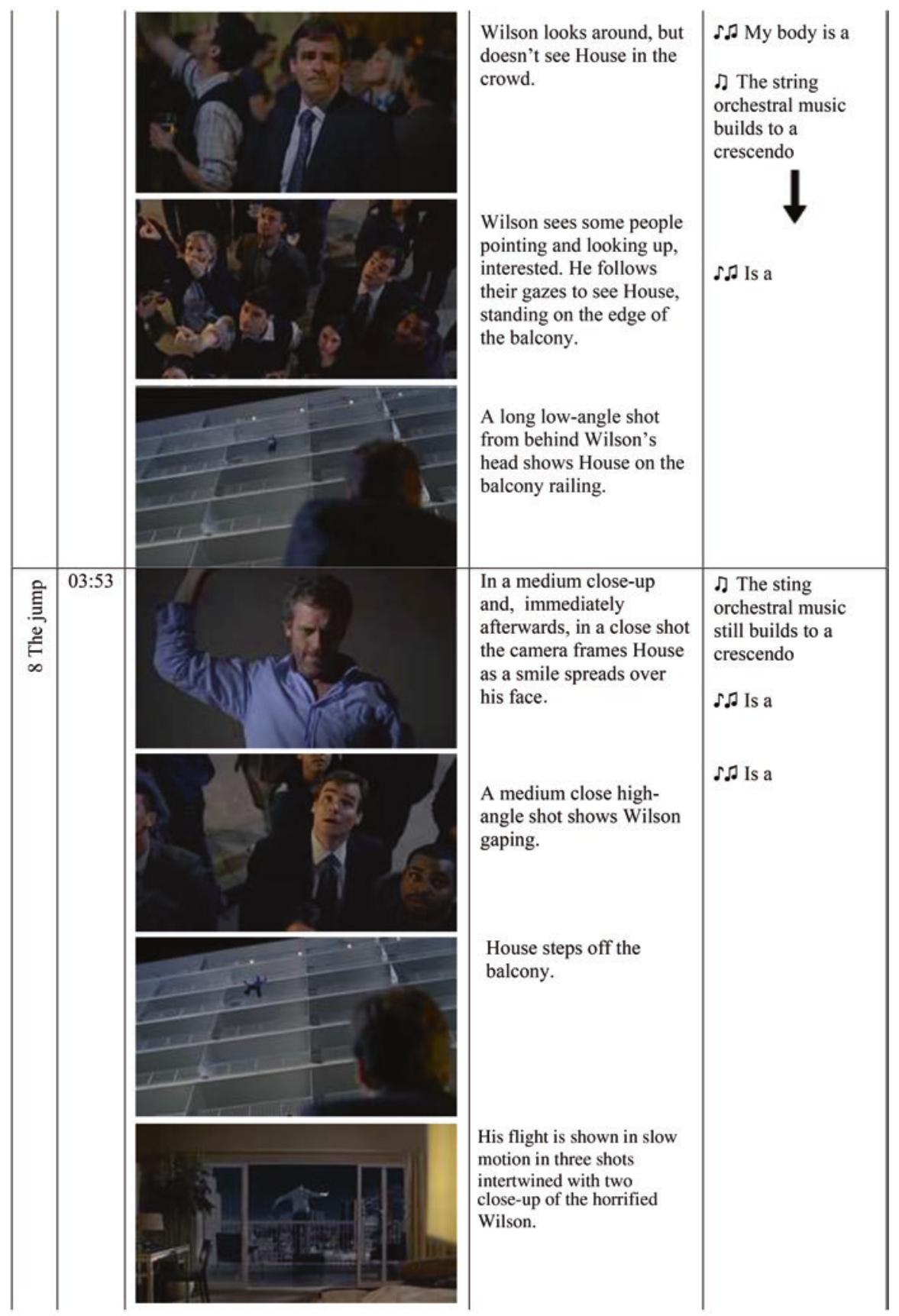




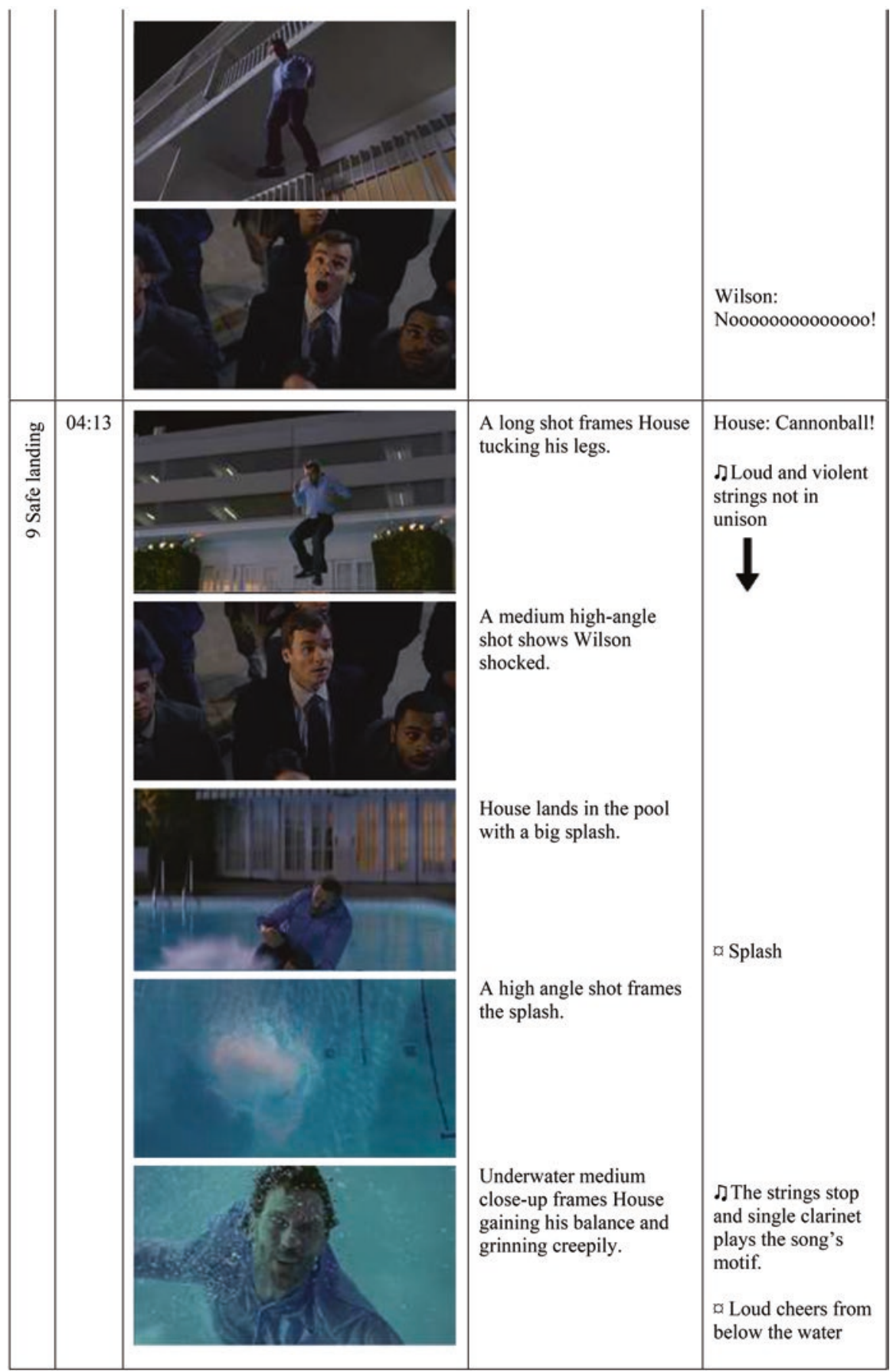




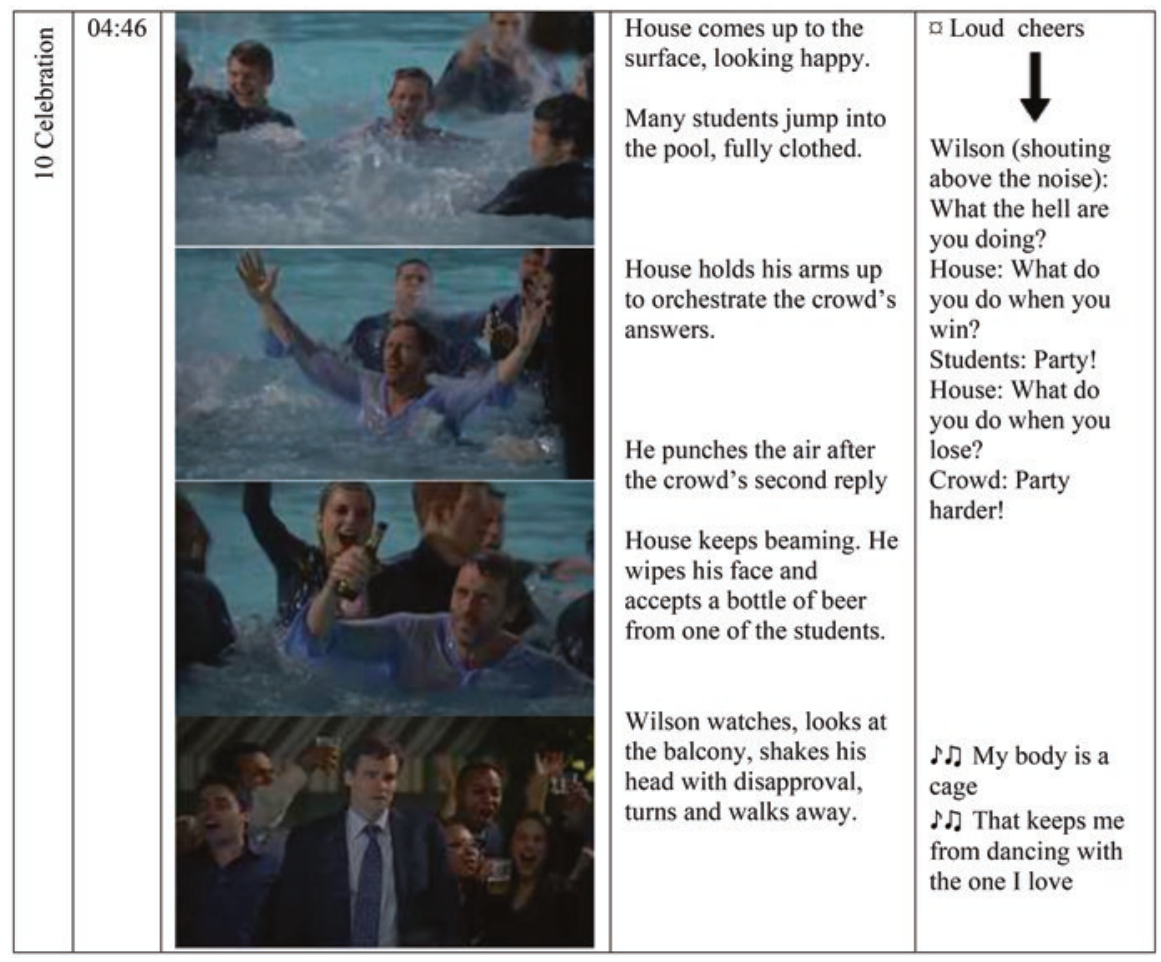

Fig. 1 Example 1. Episode 16, Season 7

In this series of consecutive phases, the multimodal abundance of clues leads the recipient to develop a false belief that House indents to (Phases 3, 4, 6 and 7), and does (Phase 8), commit suicide only to realise that this is not the case (Phase 9). The initial interaction between House and the bartender (Phase 1) indicates that the former is in a bad mood and just wants to get inebriated and dull his senses, given that Cuddy has terminated their intimate relationship. The next two Phases (2 and 3) seem to picture House as pining for the olden days that are never coming back. Mesmerised by the young people celebrating (their voices resonating in his head), he appears to be coming to a realisation that he is advanced in age, that he cannot have such fun, and that he cannot ever be happy in general. These dark thoughts are metaphorically represented by the troubling extradiegetic sounds. The close shots of House are aimed at inspiring in the recipient a feeling of intimacy and empathy with him. As the story unfolds, with the benefit of hindsight, the recipient can also conjecture that it is already in the pub that House may have come up with his suicidal plan.

This plan becomes evident when House, whilst sitting in the messy room, takes the Vicodin he has left (Phase 4) and contemplates his jump from the balcony (Phases 6 and 7), which is shown to be very high thanks to a shot from inside the room. This interpretation is reinforced by Peter Gabriel's gothic-like orchestral rendition of Arcade Fire's My Body Is a Cage, whose instrumental part comes to a climax together with the visual representation of the alleged suicide. The lyric alone 
(about mental and physical entrapment) appears relevant to House's plight (his physical handicap and the constant pain in the mutilated thigh muscle, his failure to sustain the relationship with Cuddy, and his general sense of loneliness and isolation). Another component contributing to this interpretation is the expression of fear and anxiety that draws on the face of Wilson - who has arrived to check how House is handling the post-break-up crisis (Phase 5) - when he sees his friend on the balcony railing high above (Phase 7), and his verbal reaction when House has jumped down (Phase 8). House's flight downwards is dramatically presented in various shots from different angles (Phase 8). The recipient is thus invited to nurture as long as possible the make belief that House has decided to commit suicide and has jumped to his death. It needs to be stressed that none of the characters performs any deception. Most importantly, Wilson's reactions of shock and angst are sincere given that House's dive is indeed quixotic and extremely dangerous and can easily lead to severe injuries, if not death.

The entire act of extradiegetic deception is duly revealed to the sole target, i.e. the recipient, who learns about House's genuine intentions and the nature of his actions, this time corresponding to the fictional truth. This happens when the camera narrator shows House tucking up his knees, shouting "cannonball" and landing safely in the swimming pool (Phase 9). Consequently, the recipient needs to revise the previously developed make beliefs about House's "epiphany" in the pub, and about his intentions as he was standing on the balcony railing and as he took a leap. The recipient may then infer that, regardless of how he was feeling in the aftermath of the break-up with Cuddy, House must have decided to mingle with the crowd of the partying students and to impress them with his diving stunt, thereby proving the bartender wrong.

This appears to be the prototypical inferential path the collective sender has designed for the model viewer, the recipient, to follow in order to be successfully deceived through the camera narrator's strategies. However, as is the case with any deception, not all viewers need to be taken in. Resisting to get enthralled in the fictional world, a viewer may rationalise that this is only episode 16 in the current season of House (and each season comprises from 22 to 24) and that Season 8 is planned (from the perspective of a viewer watching the televised premiere of the episode in 2013) or has already been released, and that the series cannot exist with the eponymous character, who has not shown any suicidal streak and who is usually impervious to any social influence. There are also on-screen deception-indicating cues, such as that the people surrounding Wilson (Phase 7) look amused rather than mortified when gazing up at House.

The pending query is what specific strategies of deception the cinematic narrator employs in Example 1. Four general strategies come across as being the most important. Firstly, one component of deception resides in the covert ambiguity of House's nonverbal reactions (whose significance is boosted by the close-ups, the slow motion and sounds) to the celebrating students and the inspiration he gets based on that sight. The salient and contextually relevant interpretation of his thoughtfulness (and the fact that he is devastated and even suicidal) is later disconfirmed and ousted by another one, viz. House's decision to impress the celebrating students. Secondly, seeking the relation between the seemingly unrelated consecutive scenes featuring 
the main character: the one in the pub and the one in the hotel room (taking the remaining Vicodin pills), as well as on the balcony (preparing for the jump), involves recognising the deceptive multimodal implicature that House is resigned to being drugged and committing suicide, having realised that his best time is gone. Thirdly, contrary to what purports to be manifest and what is consonant with the suicide scenario, the dramatic lyric and tune of the extradiegetic song is covertly irrelevant to the fictional reality, notably the protagonist's plans and actions. Fourthly, the camera work (its positioning and angle) performs deception via withholding information by not showing the swimming pool below House's balcony until the very moment he lands in it. This withholding information makes for another covert ambiguity underlying House's action, namely a jump to his death vs an awe-inspiring stunt.

Overall, this example proves that cinematic strategies can function as pragmatic acts (Janney, 2012) and that the cinematic narrator can communicate extradiegetic deceptive meanings multimodally, with no character being responsible for or aware of them.

\section{Intradiegetic Deception Performed by Characters}

The deception depicted in "Extradiegetic Deception Performed Only by the Cinematic Narrator" is multimodally performed by the cinematic narrator beyond the characters' level of communication only to be revealed at the end of the same sequence of scenes. This can be juxtaposed with a case of deception that is performed by characters, with the cinematic narrator merely facilitating this by "objectively" reporting the deception-driven interactions to the recipient, who is not omniscient. Also, unlike in Example 1, the scenes involving deception are scattered across the episode, the very end of which discloses the relevant truth of the fictional world. For reasons of space, only two scenes are transcribed here (Fig. 2 and Fig. 3), while the other relevant ones are only briefly summarised.

\section{Example 2: Season 5, Episode 10}

[Dr Kutner, a member of House's team, set up an online second opinion clinic in the name of Dr House. Kutner reveals this fact to Dr Taub when asking his opinion on whether a leaking breast implant can cause joint pain. Kutner involves Taub in the online business so as to prevent him from sharing the news with House.]

[Kutner tells Taub about another email from the "boob lady", who threatens to sue him if he fails to diagnose her. House is close to overhearing this conversation.]

[Taub and Kutner chance upon the patient by the name of DeeDee, a heavily tattooed blonde, in an elevator as she is on her way to see the Dr House with whom she has been exchanging emails regarding her joint paint and fatigue, as well as hair falling out in clumps. The real House, who is waiting for the two doctors vis-à-vis the elevator, catches a glimpse of DeeDee, Taub and Kutner on their way to the ER.]

[During the team's meeting, Kutner's and Taub's beepers go off. House reacts, "So who's paging you? Your wife? Does it worry you that she paged Kutner first?". After the meeting, Kutner and Taub rush off, knowing they were paged about DeeDee.] 


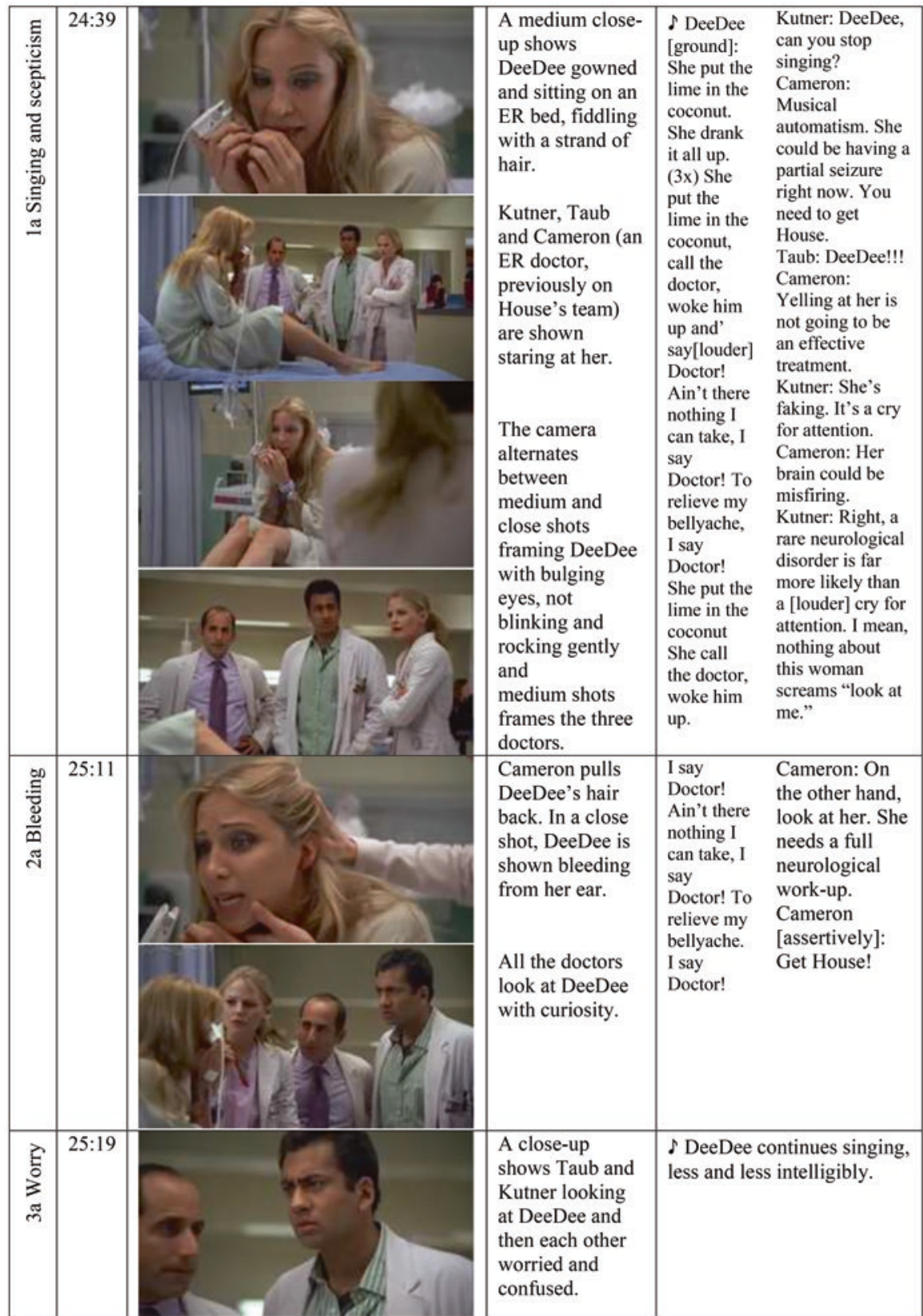

Fig. 2 Example 2, Part a 
[Kutner duly meets Dr Cameron and Dr Chase, House's former team members, in the cafeteria. Chase agrees to scan DeeDee for biliary tumour in exchange for $25 \%$ of Kutner's income.]

[Kutner and Taub reach the ER area only to find DeeDee gone from her bed. A nurse tells them that the patient had a respiratory arrest and did not survive. Kutner and Taub stare at each other in horror.]

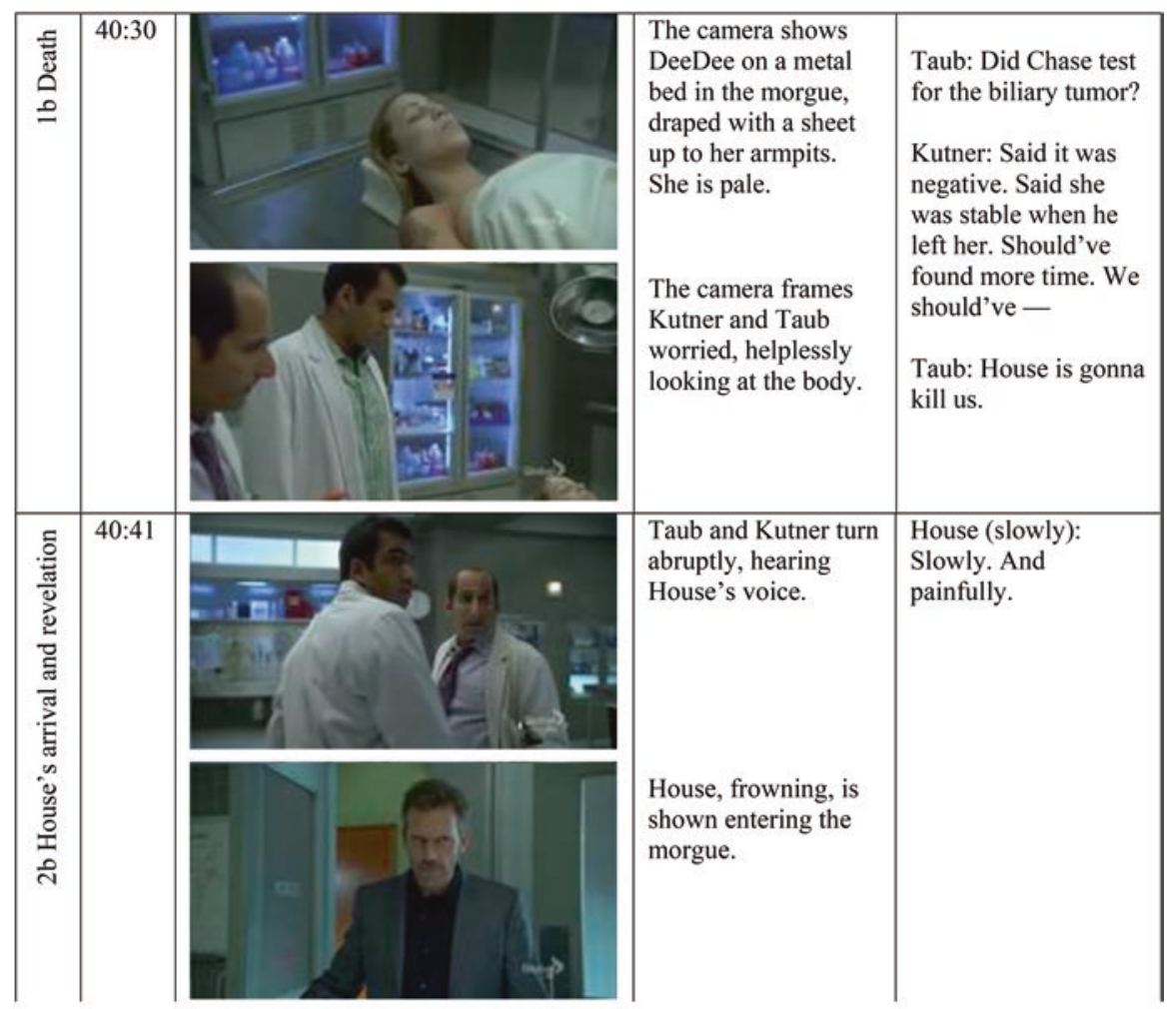




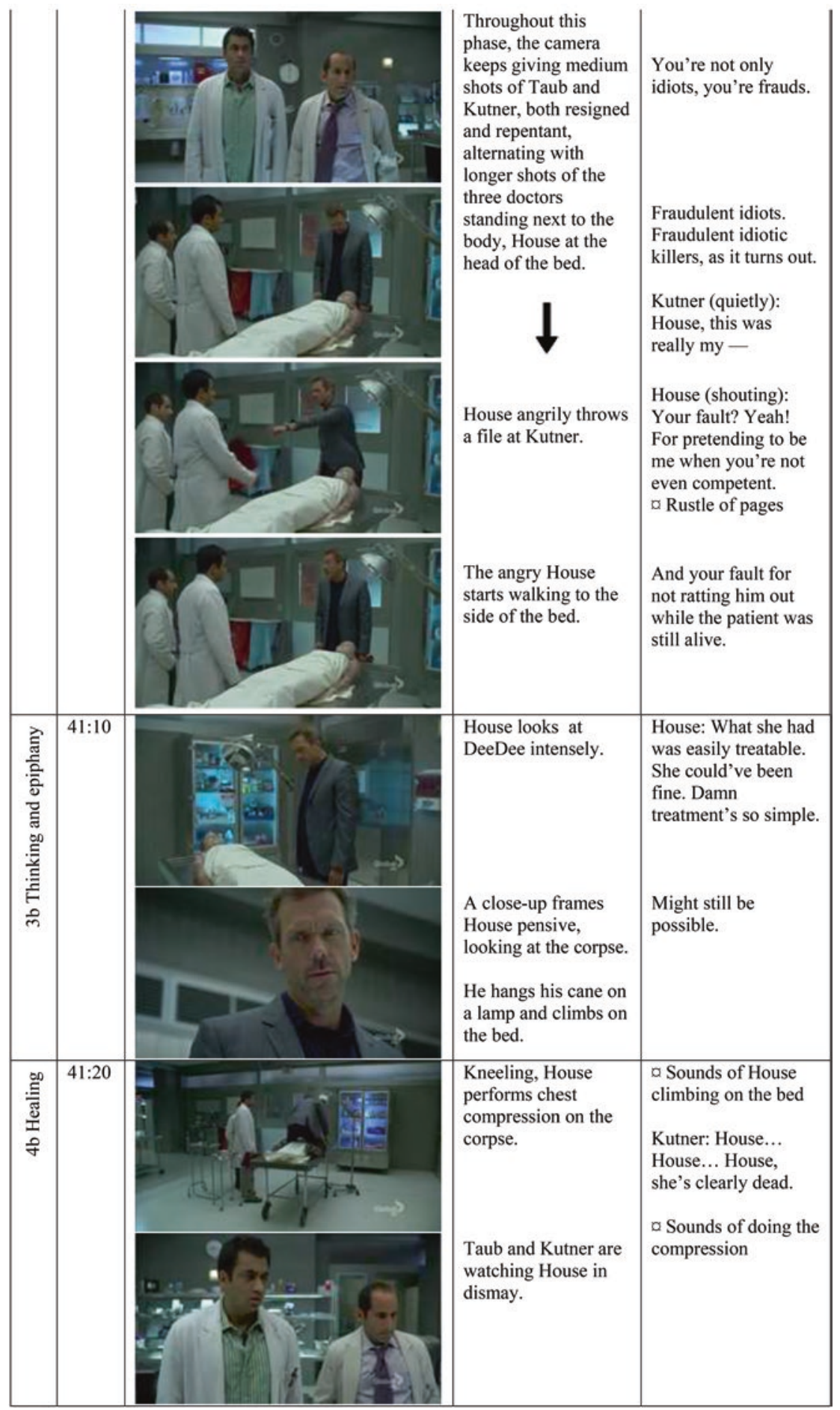




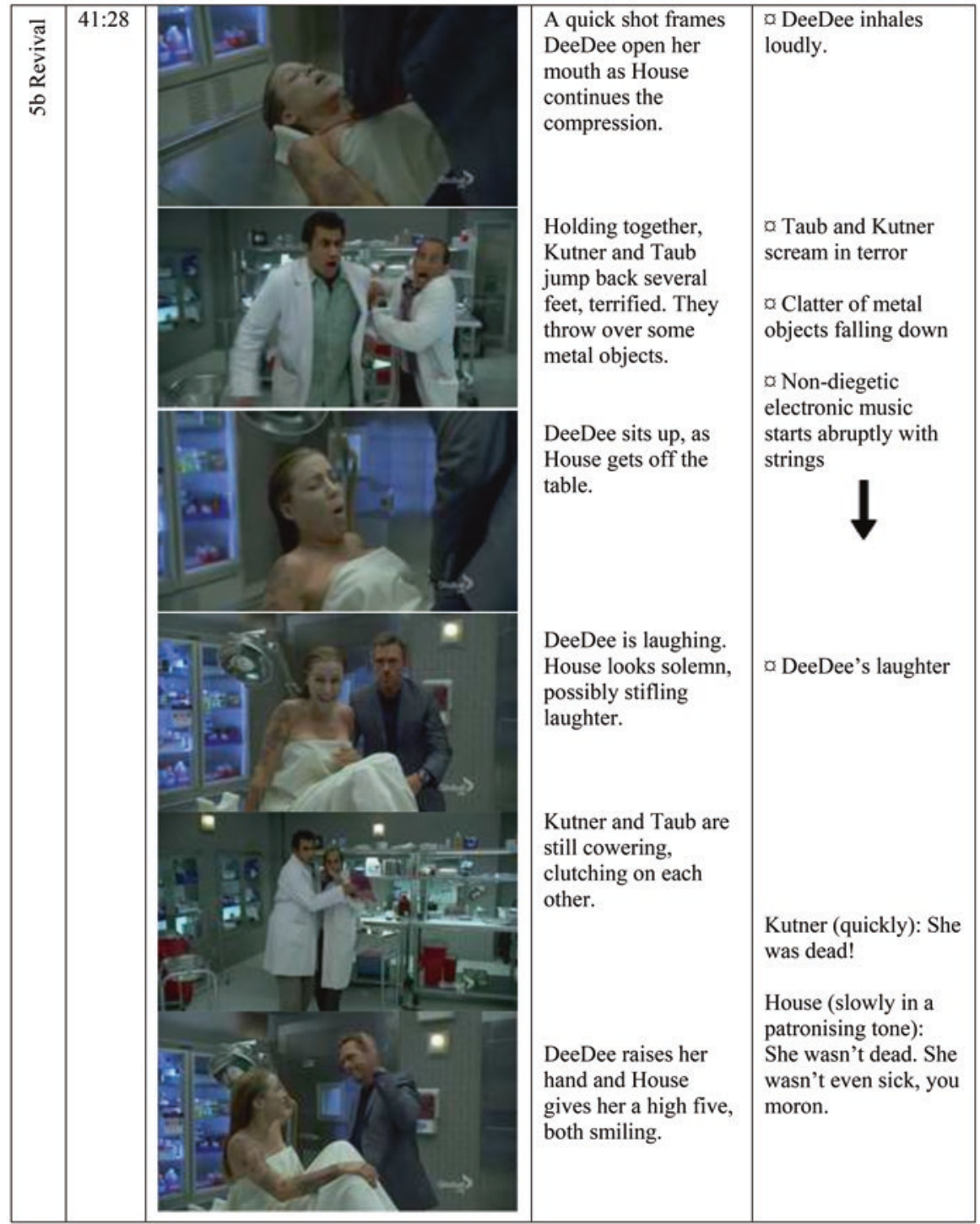




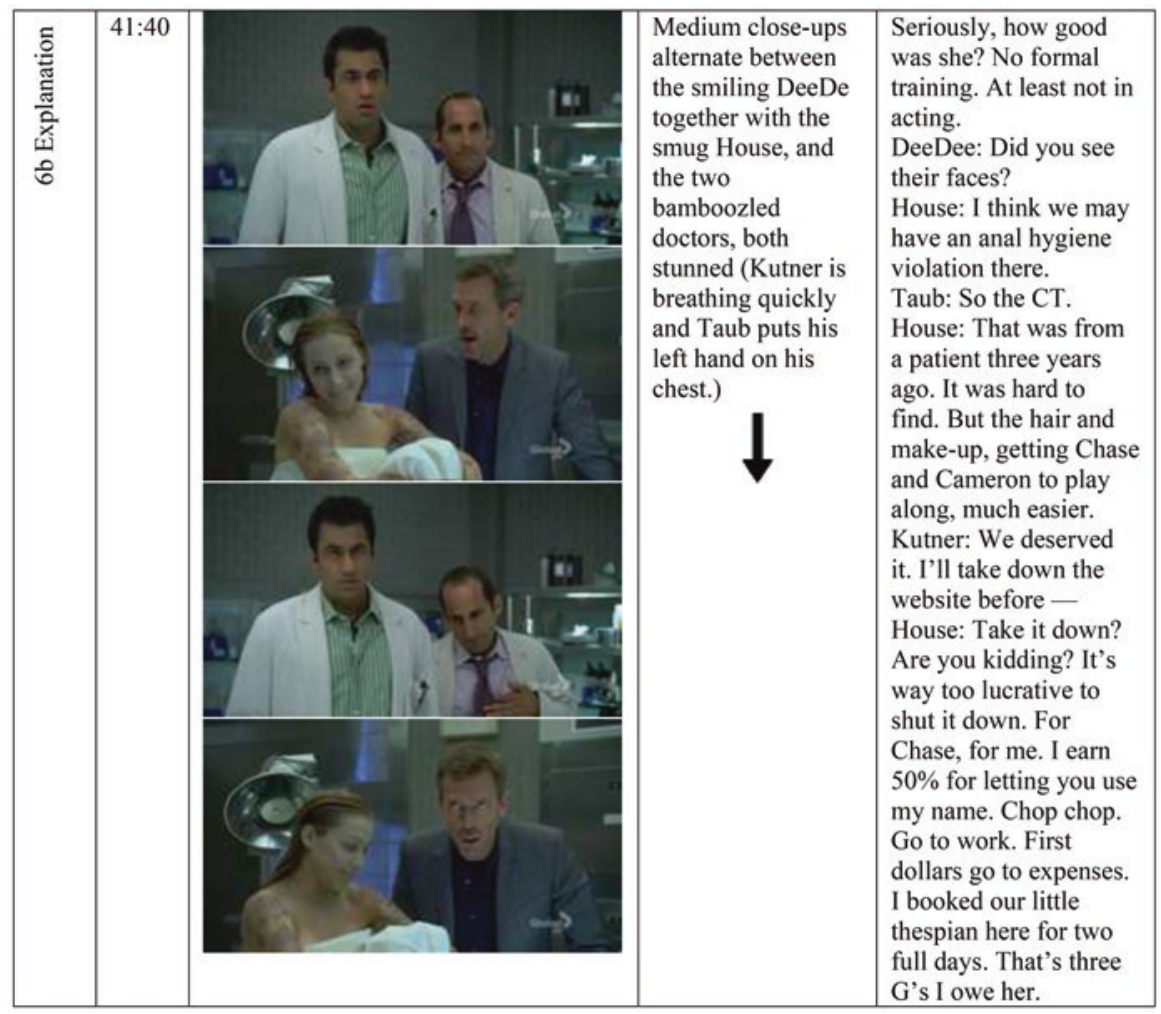

Fig. 3 Example 2. Season 5, Episode 10 (part 2)

The above strand of the multimodal narrative (interweaving with a few others in this episode) concerns an elaborate act of deception targeted at Kutner and Taub (to whose mischief the recipient is privy from the beginning, being aware that they are deceptively withholding information from House) performed by House and his accomplices, namely DeeDee (an escort), and two former members of his team, Cameron and Chase. Throughout this act, the recipient is given the perspective of the intradiegetic target, and is thus deceived, similar to the two characters, only to discover this at the end of the episode thanks to the deceivers' revelation. Essentially, House turns out to have found out about the illegitimate online business set up in his name and to have hired the prostitute to covertly pretend to be an online patient, who arrives at the hospital to feign not only strange bodily symptoms (e.g. the uncontrollable singing of Harry Nilsen's Coconut) but also ultimately death and rebirth. Additionally, as House ultimately admits (Phase 6b), he invited Cameron and Chase to falsely corroborate the symptoms. All the deceiving characters perform verbal deception, mainly through lies, i.e. covertly untruthful assertions (e.g. Cameron's "She could be having a partial seizure right now" in Phase 2a, and House's "What 
she had was easily treatable", "She could've been fine" and "Damn treatment's so simple" in Phase 3b), as well as non-verbal deception, such as covert pretending to be dead (Phase 1b).

In principle, intradiegetic deception performed on the characters' level of communication can display the same forms as deception in real-life interactions (Dynel, 2018), being facilitated by cinematic strategies so that the recipient can be deceived too. The cinematic narrator carefully presents the relevant deceptive meanings (e.g. close-ups of the bleeding ear in 2a), whilst deceptively withholding crucial information (e.g. no scenes of House inviting his accomplices are present, and nor are those involving DeeDee's preparation for the acts of deception). Also, the success of the deception of the recipient is co-determined by the genuine reactions of the diegetic targets manifest in the close-ups, as in Phases $3 \mathrm{a}, 1 \mathrm{~b}$ and $4 \mathrm{~b}$ ). The same holds for the pleasure-giving surprise when House's prank is revealed (Phase 6b), the effect being boosted by the quick shots of DeeDee inhaling and the two petrified doctors jumping back, in tandem with the tension-boosting extra-diegetic music. These strategies help deception succeed despite some cues for the deception that observant viewers may notice (e.g. Cameron notices the blood coming from DeeDee's ear even though it does not really show until the former pulls the hair back in Phase 1a).

As this example indicates, film deception may be performed strictly by characters interacting in the fictional/diegetic world, which, thanks to complex cinematic strategies, imitate real-life interactions that one eavesdrops on, with the interlocutors' being oblivious to this fact. The receiver is deceived in tandem with the characters until being allowed to discover the fictional truth with the benefit of hindsight. The revelation may sometimes come at the very end of the film or in the same interaction. (On the other hand, deceptive acts rendered by a character towards another/others may be highly transparent to the recipient, who is never meant to be deceived, in which case there is no deceptive unreliability on the cinematic narrator's part.) When a character commits an act of deception targeted at another character, he/she cannot ever be considered to have intended to deceive the recipient. A character is a fictional inhabitant of a fictional world oblivious to the recipient, who has access to the fictional world thanks to the cinematic narrator, not deceptive per se. It is, however, the collective sender who aims to deceive the recipient, using the characters as their mouthpieces and the cinematic narrator as a seemingly "unbiased" reporter that withholds some information to facilitate the deception.

Overall, the different forms of deception that arise in a fictional world inhabited by characters are amenable to the same theoretical considerations as deception in real-life interactions, which fictional interactions aim to imitate (see Dynel, 2016, 2018). The recipient is offered, albeit frequently only in retrospect, insight into the interactants' intentions and beliefs and hence their (un)truthfulness, with various discursive and cinematic strategies facilitating their understanding. 


\section{Deception Performed Jointly by the Intradiegetic and Cinematic Narrators}

The third type of deception, which is very often mentioned in the literature on the narrator's unreliability in film (see "Can the Cinematic Narrator Lie or Just Deceive Otherwise?"), comes into being when the two categories of film deception presented in the previous two sub-sections co-occur. This happens when an interactant on the characters' level becomes an intradiegetic narrator and deceptively recounts a story which is presented on screen in the form of a flashback, with both the narrator's utterances and the multimodal representation being covertly untruthful relative to the fictional world and its truth. An intradiegetic narrator is also known as an invoking narrator (Black, 1986), for it is a character whose words invoke a multimodal illustration of the verbal narrative.

It is widely acknowledged that a character-narrator on the diegetic level can lie in literary fiction (Ryan, 1981) and in film (Burgoyne, 1990: 7). An intradiegetic character-narrator "can lie (...) or distort the facts of the fictional world" (Stam et al., 1992: 102) in order to deceive the interlocutor (cf. deception at the characters' level of communication in "Intradiegetic Deception Performed by Characters"), which can be coupled with an "untruthful account, in flashback", ${ }^{11}$ with the camera being "at the service of the narrator" and conspiring with him/her (Chatman, 1978: 237). In this vein, Kozloff talks about visual "presentation" that "colludes with the narrator's false [-believed] account of events" (1988: 115). ${ }^{12}$ On the other hand, as Chatman (1978: 235) states, "a voiceover depicting events and existents in the story may be belied by what we see so clearly for ourselves." Alternatively, an intradiegetic narrator may only introduce the multimodal cinematic narrator's presentation of a previous verbal interaction in its entire form, as is the case with Example 3 (see Fig. 4 and Fig. 5).

\section{Example 3: Season 2, Episode 8}

[Stacy, the hospital lawyer, is investigating the case of Dr Chase's alleged malpractice, as a result of which a patient died. She has just learnt from Chase that the patient had liver transplant, her brother donating the organ, and that it was House who had arranged for a surgeon to do this live donor transplant on very short notice. This scene of the interaction between Stacy and Chase cuts to what follows.]

\footnotetext{
${ }^{11}$ If no such flashback is present, the deception is restricted to the characters' level.

${ }^{12}$ Kozloff (1988) also claims that only the "camera narrator" may deceive the viewer, while the narrating character is truthful. Such a case, if at all possible, would qualify as the type of deception presented in "Extradiegetic Deception Performed Only by the Cinematic Narrator". On the other hand, one may also envisage the opposite scenario; the camera narrator may give a truthful account and so reveal the fact that a character is lying, or generally deceiving, through a narrative. This qualifies as intradiegetic deception ("Intradiegetic Deception Performed by Characters"), to which the recipient is privy. This is the case with a scene from Ang Lee's Brokeback Mountain, when the wife mendaciously reports on the circumstances of her husband's death to his male ex-lover, while the cinematic narrator presents different events, which are to be interpreted as corresponding to the fictional world's truth.
} 


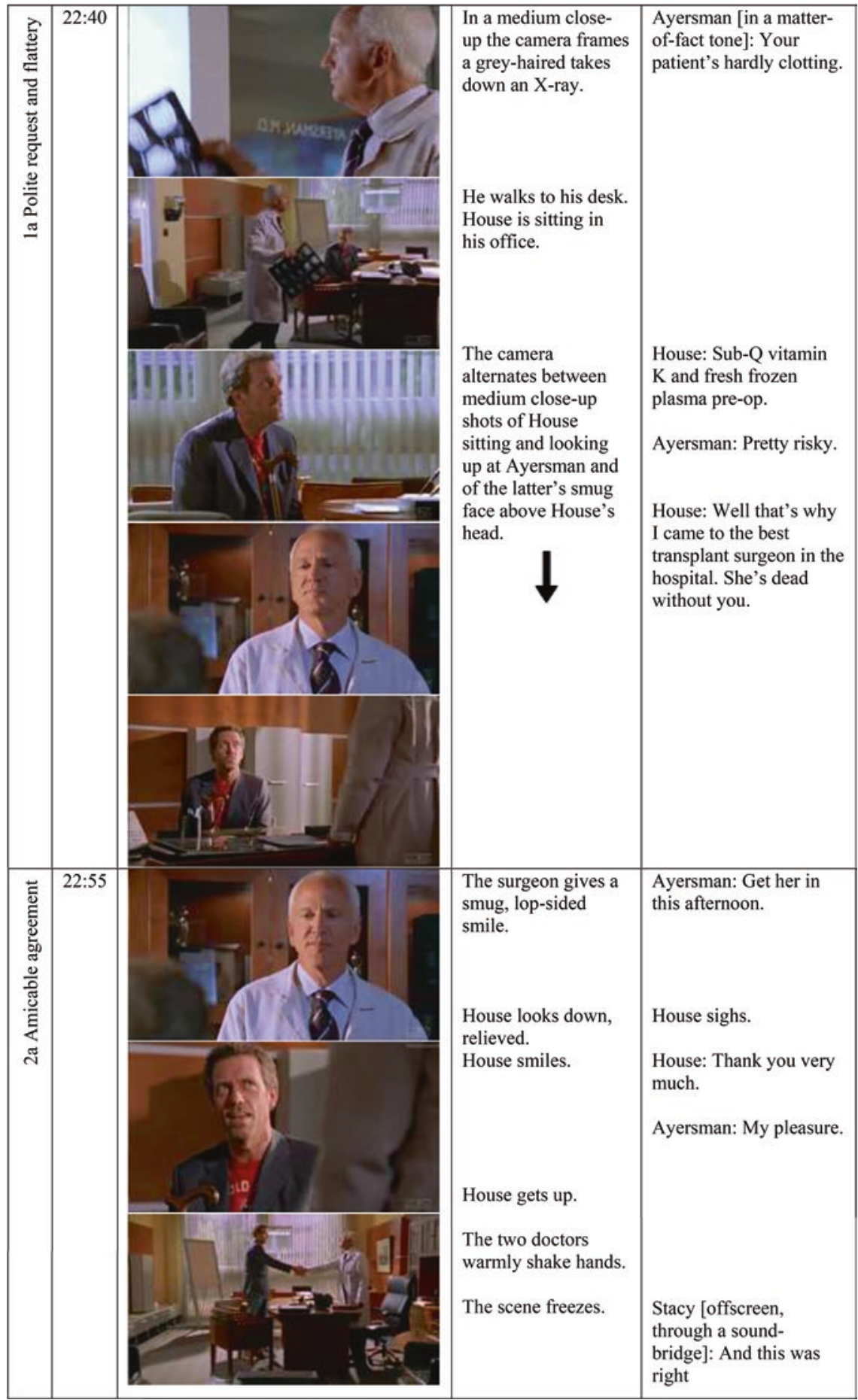




\begin{tabular}{|l|l|l|l|l|}
\hline 23:02 & $\begin{array}{l}\text { Scene cuts to a close } \\
\text { shot of Stacy, } \\
\text { sceptical, talking to } \\
\text { an interlocutor. }\end{array}$ & $\begin{array}{l}\text { before you ran the } \\
\text { marathon, I suppose? }\end{array}$ \\
\hline & & $\begin{array}{l}\text { A medium close-up } \\
\text { frames House } \\
\text { wincing. }\end{array}$ & $\begin{array}{l}\text { House: Was it the part } \\
\text { where he warmly } \\
\text { clasped my hands in } \\
\text { thanks, was that too } \\
\text { much? }\end{array}$ \\
\hline
\end{tabular}

Fig. 4 Example 2, Part a

[Stacy is adamant that House should tell her the truth as, in her capacity as his attorney, she cannot tell anybody. Another flashback follows.]

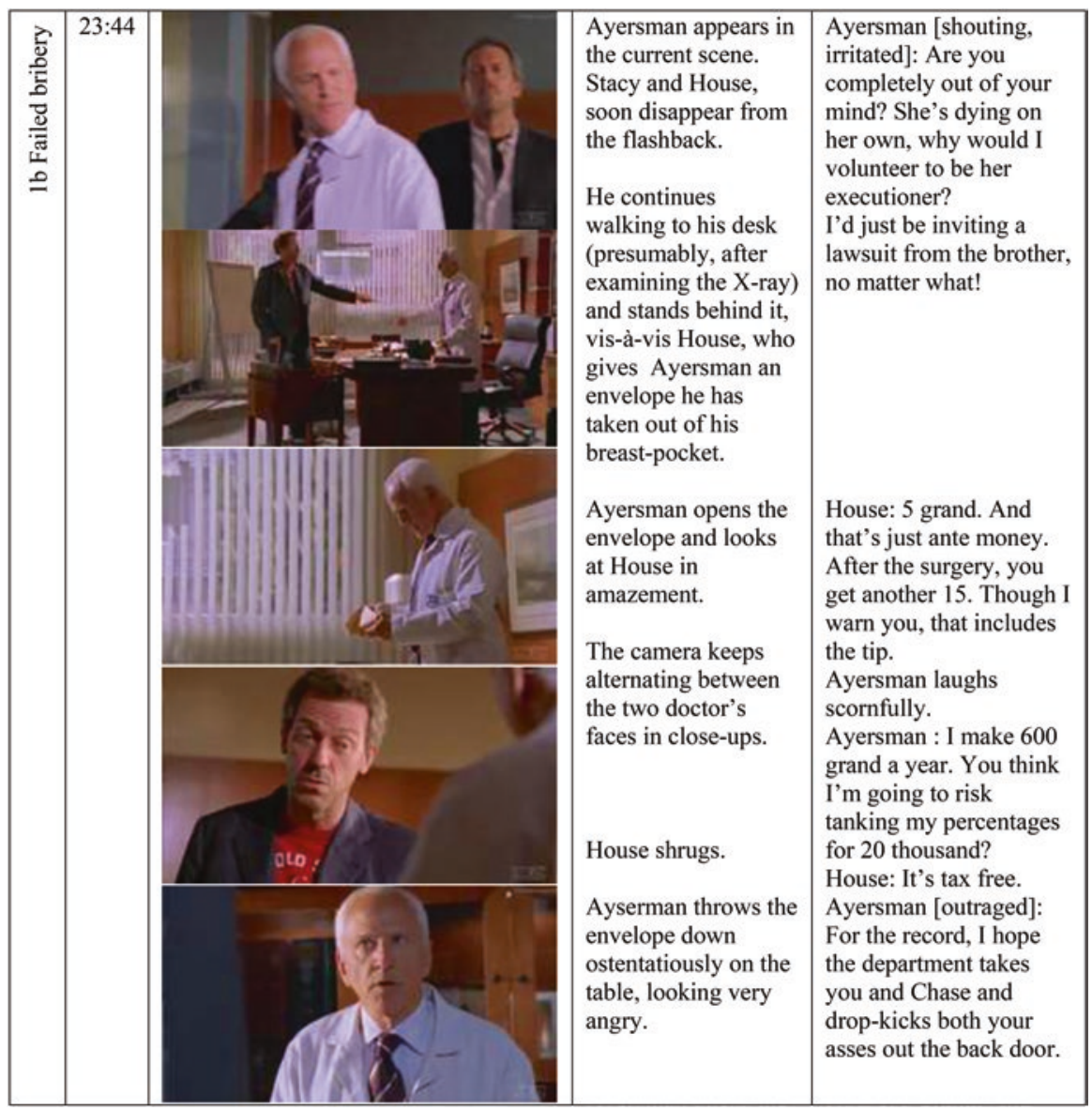




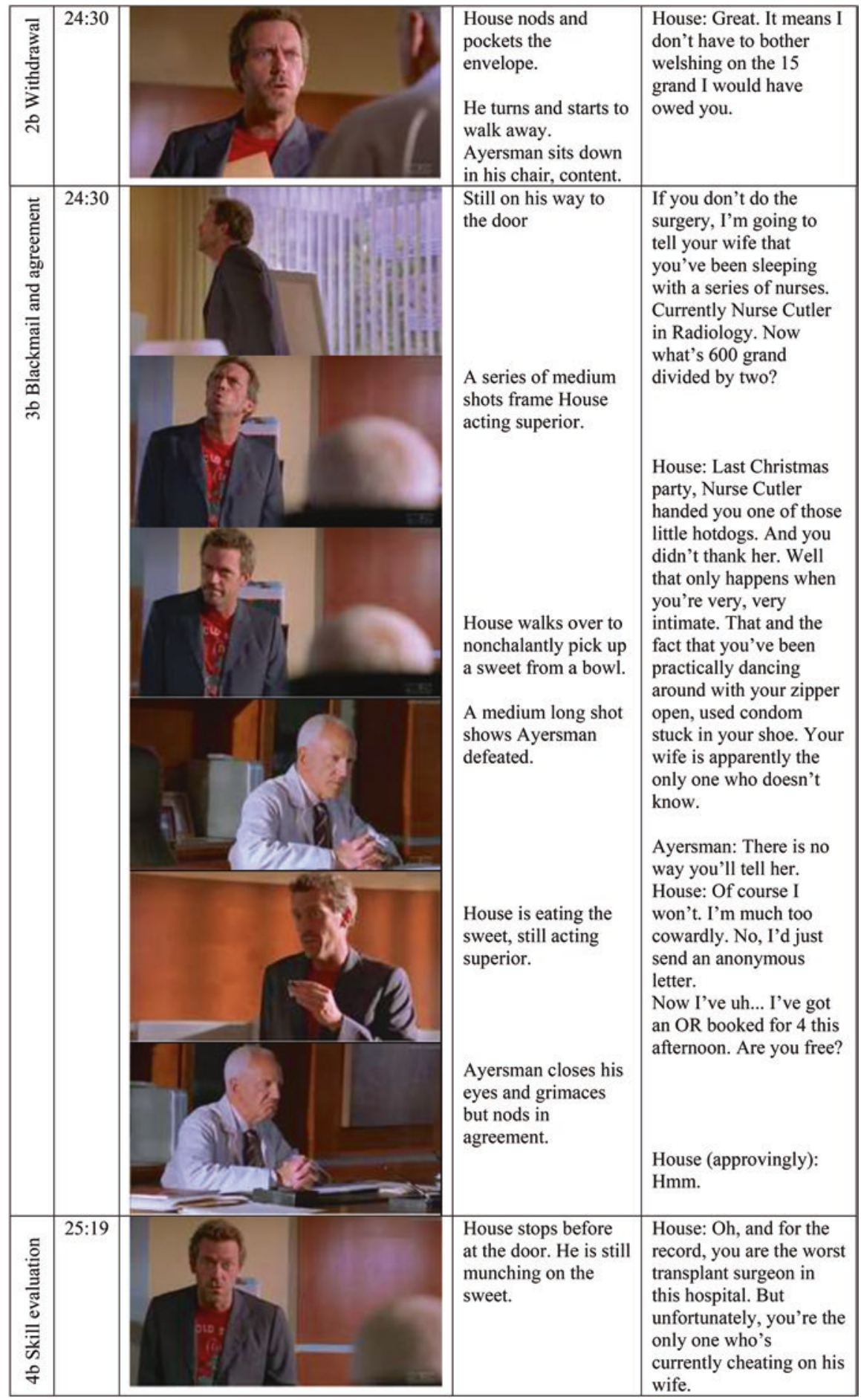

Fig. 5 Example 3, Part b 
This example presents an act of verbal deception performed by the intradiegetic narrator, a character who is simultaneously one of the two interactants in conversation in the flashback presented by the cinematic narrator. The cinematic narrator takes the position of the intradiegetic narrator's mouthpiece, reporting to the recipient what the latter is telling Stacy in the current interaction in a multimodal manner (Phases 1a and 2a). Stacy sees through House's deception (Phase 3a), which prompts him to give a truthful, as it seems, account of his interaction with the surgeon: the unsuccessful attempt at bribery (Phase 1b) and on the successful blackmail (Phase $3 b)$. This second account sheds new light on the preceding narrative, revealing its deceptive nature also to the recipient. Therefore, the first flashback (Phases 1a-b) turns out to have been riddled with lies. The only truthful aspects, the ones true in the fictional world, seem to have been that House did go to meet the surgeon in his office so that the latter would do the transplant, and the surgeon did examine the patient's X-ray. Nonetheless, all the utterances and non-verbal messages exchanged by the interlocutors turn out to have been House's lies. It can be surmised that House was not friendly, House did not politely ask or cajole the surgeon into doing the transplant through flattery, the surgeon did not give a smug smile or agree to do the risky procedure thanks to House's ingratiation, the two doctors did not shake hands, etc.

All the mendacious messages in House's intradiegetic narrative (Fig. 4), which would take numerous utterances to be conveyed in the form of a verbal account, are neatly communicated on screen in a multimodal manner by the cinematic narrator. The latter thus presents the interaction that never took place in this form and is rife with deception, specifically multimodal lies (see "Can the Cinematic Narrator Lie or Just Deceive Otherwise?"). Needless to say, cinematic techniques collude with the character narrator's deceptive account and enhance the effect of the deceptive utterances and interactant's non-verbal messages presented as an interaction. For instance, in Phases 1a and 2a, the camera frames the surgeon as looming over House, as if he is superior towards the latter, which is covertly untruthful, given House's contemptuous attitude towards him.

Two interesting points are worth addressing with reference to this example. The revelation flashback contains a nested act of momentary deception targeted at the surgeon and performed non-verbally by House, which is non-deceptively reported on by the cinematic narrator and the intradiegetic narrator. In Phase $2 b$, House purports to be retreating (as he takes the envelope and heads for the door) only to attack again and manipulate the surgeon through blackmail. On the other hand, the cinematic narrator seems to be responsible for another manifestation of deception that is independent of House's mendacious account. A viewer may interpret the flashback as being a representation of Chase's account in the preceding scene. Based on a dialogue hook and discontinuity editing (see Bordwell and Thompson 2013 [1979]), the recipient can rightly infer that the grey-haired man on screen must be the surgeon just mentioned by Chase (a multimodal implicature generated through the Gricean Relation maxim flouting), and that the interaction on the screen is another flashback of Chase's. However, it is only in Phase 3a that the recipient realises that the narrator is House, rather than Chase. The recipient is thus deceived about who the intradiegetic narrator is through the cinematic narrator's withholding information (editing out) of the scene that shows a change in Stacy's interlocutor. 


\section{Can the Cinematic Narrator Lie or Just Deceive Otherwise?}

Previously, deception in film has been most often addressed with reference to what was presented in the section "Deception Performed Jointly by the Intradiegetic and Cinematic Narrators": the intradiegetic narrator (Genette (1980 [1972]) gives a deceptive account of prior events, with the cinematic narrator presenting it in a flashback (Chatman, 1978; Kozloff, 1988; Stam et al., 1992). Claims have been made that in such a situation the camera narrator seems to be able to "lie", contrary to the well-established convention (Chatman, 1978: 237, 1990: 132; Kozloff, 1988: 115; Anderson, 2010). This case (cf. Example 3 here) is typically illustrated with the (in)famous example of Alfred Hitchcock's Stage Fright, at the beginning of which the main male character, Johnny, is talking to Eve and recounts a falsebelieved story of his meeting with Charlotte. A crossfade to Jonathan in his kitchen indicates the beginning of a "lying flashback", in which the multimodal presentation "colludes with the narrator's false account of events" (Kozloff, 1988: 115). This scene is known to have caused an angry outcry from critics (Kozloff, 1988). Bordwell (1985: 61) concludes that the narration is "duplicitous (...) by appearing to be highly communicative - not just reporting what the liar said but showing it as if it were indeed objectively true." In this vein, Anderson (2010: 84) observes that by "invoking the conventions for a flashback, but presenting instead a dramatization of Johnny's lie, the film misreports diegetic events- the film lies to us." Interestingly, Hitchcock himself considered this a mistake with the benefit of hindsight, "I did one thing in [Stage Fright] that I never should have done; I put in a flashback that was a lie" (Truffaut, 1983: 189). This kind of lie is also considered a violation of the basic principle of extradiegetic narration (Thompson 1977). However, as evidenced by Example 3, Hitchcock's lying flashback is by no means an isolated incident, and this narrative strategy is indeed employed in contemporary cinematography. Many philosophers have tried to vindicate Hitchcock's cinematic strategy, or at least, account for its workings in the light of narrative theory.

Casetti (1986), proposes that the "false" images (and also utterances, which he ignores) represent what the narrating character's addressee pictures in her head while listening to the homodiegetic narration. However, it is intuitive to assume that "the deceptive images and their juxtaposition must be thought of as representations of Johnny's account, though we begin by taking them also to be representations of what is real with the fiction itself" (Currie, 1995: 27, emphasis in original). Following the same premise, Chatman (1986: 141) goes a step further and states that, when the flashback is used, Hitchcock's Johnny is the only narrator and "everything we see and hear originates with him (...) since every cinematic tool - editing, lighting, commentative music, etc. - contributes to his intention." Chatman (1990: 132) maintains that a narrating character like this "is 'responsible' for the lying images and sounds that we see and hear", and he invokes the role of the invariably reliable implied author, who does allow the facts to emerge ultimately. In a similar vein, Burgoyne suggests that the intradiegetic narrator in Stage Fright is responsible for the multimodal lying flashback which relies on using both images and characters' utterances and that the cinematic narrator "controls the entire cinematic apparatus" (1990: 11). 
Burgoyne (1990: 7) thus claims that a personal character-narrator (on the intradiegetic level) can utilise not only words but also the multimodal tools available to the cinematic narrator in order to salvage his central premise that the cinematic narrator cannot lie but can retroactively invalidate the intradiegetic narrator's false account. This explanation results in conflating the narrative of the intradiegetic character narrator with the narrative that only the cinematic narrator can produce.

The views endorsed by Chatman $(1986,1990)$ and Burgoyne (1990) are not entirely appealing. Surely, although the mendacious account originates with a character like Johnny, he cannot lie to us, the viewers, for "he is unaware not only of us but of the world we inhabit" (Anderson, 2010: 88). Additionally, as Currie (1995: 27) rightly observes, this narrating character "exists within the story, and it is no part of that story that he produced and edited cinematic images in order to convince his fictional fellows (and us?)". It is then impossible for a character to be in charge of various cinematic techniques, which would involve his/her ontological superiority over the story in which he/she partakes (Anderson, 2010). The tools that the two narrators, intradiegetic and cinematic, have at their disposal are fundamentally different. The cinematic narrator can tell a false-believed story in a flashback showing a distorted interaction or just images while the intradiegetic narrator can produce only an oral narrative.

The pending question is then who deceives and who discloses the deception to the recipient. For his part, Currie (1995) proposes that it is an implied author who reveals the extradiegetic narrator's deception to the viewer. Nonetheless, the "implied author" seems to be an otiose concept proposed, besides real authors and narrators, by many scholars (e.g. Booth 1983 [1961]; Chatman, 1978, 1990; Currie, 1995; Stam et al., 1992; cf. Sternberg \& Yacobi, 2015 and references therein). Arguing against Chatman's (1978) implied author (necessitating an implied reader), as the creator of fiction (besides the narrator, i.e. the presenter), Bordwell (2008) rightly states that the agents in the process of fiction reception are real authors and receivers, rather than the unreal agents that Chatman proposes. However, Bordwell's (2008: 128) metaphorical roller-coaster explanation - "I don't have to imagine a ghostly intelligence standing between the engineer and me, shaping the thrills and the nausea I feel" - misses the basic fact about film watching: it is based on make believing about the fictional narrative, rather than experiencing non-narrated real stimuli, such as a roller-coaster ride. Also, immersed in the fictional world, the recipient does not take cognisance of the film production crew (or literary authors), the real but hidden (rather than "implied" for the recipient to infer) authors, who stand behind extradiegetic narrators telling the story. In any case, the notion of "implied author" is not endorsed here, based on Ockham's razor, the principle of theoretical parsimony.

Here, preference is shown for this simple explanation: the cinematic narrator (representing the collective sender) legitimately deceives, specifically lies to, the recipient (while the narrating character deceives the addressee) only to disclose this later. Thus, the multimodal narrative shown in a flashback is not the product of the intradiegetic narrator at all (who can only be held accountable for a running verbal commentary), ${ }^{13}$ but rather the cinematic narrator, the entity responsible for the

\footnotetext{
${ }^{13}$ Sometimes such a commentary may run off-screen and accompany the silent flashback images.
} 
whole film communication (indirectly, also the intradiegetic narrator's verbal account), as constructed by the collective sender. Incidentally, the recognition of the fact that narrative deception is not an immoral but rather pleasure-giving strategy purposefully employed by filmmakers might have pre-empted the need to account for who the guilty party is. The film production crew behind the unreliable cinematic narrator does deceive the recipient with regard to some aspect of the fictional world, leading the latter to develop false make beliefs. However, all film deception (regardless of how it is performed) is ultimately revealed, giving the recipient a pleasurable surprise (see Dynel, 2013).

Overall, the prevalent view about the illegitimacy of multimodal lies, and hence by extension, all deception in fiction may be consequent upon the traditional wellentrenched view that heterodiegetic narration, especially when impersonal (cf. Ryan, 1981), ${ }^{14}$ rules out unreliability. Many authors have followed Doležel's (1998: 149) claim that the heterodiegetic narrator "cannot lie or err" given the performative nature of his heterodiegetic narration. This narrator, who has authentication authority, is responsible for the creation of the fictional world, being unable to "distort" or "falsify" it (Cohn, 2000: 311), unlike a homodiegetic personal narrator, who merely reports on the events. The reason why the narrator might be regarded as inherently reliable, or here truthful, is that "in fictional communication, the text constitutes the reader's sole source of information about the represented state of affairs", which involves the recipient's "taking the fictional world to exist independently of the narrator's declarations, while using these declarations as material for construing this world" (Ryan, 1981: 530). Consequently, "[e]verything the impersonal [extradiegetic] narrator says yields a fact for the fictional world" and his "lack of personality protects him from any kind of human fallibility" (Ryan, 1981: 534).

Nevertheless, unreliable narration, and thus deception, are actually commonplace not only in homodiegetic narration but also in heterodiegetic narration (see also Zipfel 2011). With reference to unreliable literary narration, Stühring (2011: 96) states that a reader can be deceived about fictional facts in two ways, either by being given "wrong" information via "what is said" about what is the case in fiction, or by having relevant information withheld from them "at the point where it would have to be given". Essentially, these two cases seem to correspond to two forms of deception: lying and withholding information respectively. Similarly, claiming that narrators perform three main roles (reporting, interpreting, and evaluating), Phelan (2005) proposes that each shows a "mis-" category and an "under-" category, which reflects a contrast between being "wrong", i.e. false-believed, and being "insufficient", which again appear to be consonant with lying and withholding information respectively.

A weaker view seems to hold that the extradiegetic impersonal narrator, i.e. the cinematic narrator, cannot lie but can be deceptive otherwise, without making mendacious multimodal assertions. Many authors seem to have advocated this view, even if not labelling technically the forms of deception (other than lying) involved.

\footnotetext{
${ }^{14}$ It should be noted that homodiegetic narrators are always personal, while heterodiegetic narrators can be personal or impersonal, with the two being often addressed collectively. The notion of heterodiegetic impersonal narrator is the most important here.
} 
Although philosophers of fiction rarely discuss formally the categories of deception known in philosophy (see Dynel, 2018 for an overview), some relevant observations have been made regarding unreliable narrators in literary works (cf. the paragraph above). These may be seen as pertinent to the camera narrator's deceptive multimodal messages in films. As Burgoyne puts it, "[b]ecause the narrator produces the discourse through which the viewer reconstructs the fictional world, this discourse comprises the facts of the fictional universe, which always carry the value of authenticity. Consequently, the discourse of the impersonal narrator in film is always reliable in the most basic sense: this type of narrator cannot lie about the fictional world, although the narrator can withhold information and cause the spectator to make incorrect inferences" (1990: 7).

Withholding information is indeed frequently addressed as a strategy of the cinematic narrator's deception. For instance, according to Fink (1982: 24), there is a "silently accepted convention" that on-screen presentations "may omit something but never distort the truth"15 and so they can never be "false". Kozloff (1988: 115) also allows for the fact that film images can involve a partial presentation of what is true in fiction. Referring to a voice-over flashback in a screen adaptation of Agatha Christie's Evil under the Sun, Kozloff (1988: 115) reports that the "two murderers, naturally, lie" as they are recounting their alibi to Poirot, while the flashbacks shown on screen are "not false" but are "just partial". ${ }^{16}$ Regardless of whether the narrating characters are telling lies and/or performing other forms of verbal deception in practice, technically, the "partial" shots do deceptively withhold information (Dynel, 2018 , 2019) through elliptical editing, as well as camera distance and angle, which allow some crucial information to remain covert from the recipient's perspective.

For his part, Koch (2011: 70) addresses "mimetically deceptive" unreliable narration of films, such as A Beautiful Mind, that "play out a delusive strategy by way of the presentation of distorted fictitious sense-data that are not marked accordingly." Thus, the key narratorial characteristic of such films is "not misrepresenting the fictitious world but presenting someone who misperceives it," or more adequately presenting this character's distorted view of the fictional world (Koch, 2011: 70). This explanation is relevant to some of Elsaesser's (2009) "mind game films" and to some of Klecker's (2013) "mind-tricking narratives". In these cases, the cinematic narrator offers multimodal representations of the focalising characters' (Anderson, 2010) genuine lived mental experience that actually diverts from the fictional reality, about which the recipient is retroactively informed. What the cinematic narrator initially presents as the diegesis later turns out to have been, in total or in part, something untruthful relative to the fictional world, being the focalising character's figment of imagination, hallucination, delusion, dream, etc. Thus, the recipient needs to backtrack on the meanings generated based on the previous scene(s) or even the entire film and reframe them as being the character's figment of

\footnotetext{
${ }^{15}$ Technically, this distortion of truth can be performed by various means, not only through lying, which Kozloff (1988) seems to have in mind.

${ }^{16}$ The same shots, albeit re-edited are used later at the end of the film to illustrate Poirot's account of what he believes to have happened (his believed truth - and given Poirot's infallibility, objective truth - in the fictional world).
} 
imagination, hallucination, delusion or dream, which does not correspond to the fictional world and its truth. This broad category of film deception originates from the primary source of the representation: it is not the omniscient and infallible cinematic narrator's perspective but the focalising character's perspective affected by his/her mental state that modifies the fictional reality or is completely divorced from it, which the cinematic narrator merely reports. The challenge of the production crews collective sender in such films is "to avoid shots that amount to forthright false statements or, in other words, to provide a twist that allows, resorting to poetic licensing, for a consistent ex post facto reconstruction of the complete discourse" (Koch, 2011: 74). However, it may be contended that multimodal lies are not ruled out, with the cinematic narrator presenting interactions or events that are the focalising character's mental creations from start to finish but not the truth of the fictional world, as is typically the case with dreams shown on screen, unannounced; or a character's personified figment of imagination representing the character and interacting with others in the fictional world. Such untruthful (relative to the fictional world) assertoric messages are not considered lies given the retroactive reframing.

This kind of focalising/filtering through characters, who may be adjudged tacit, deceptively covert intradiegetic (unintentionally) unreliable narrators, ${ }^{17}$ is usually restricted to the representations of the diegetic world determined by the characters' experienced mental states, whether involuntary (dreams or hallucinations) or voluntary (imaginings). However, focalisation may also be done through a character's mendacious narrative, which has been depicted as a markedly different form of the cinematic narrator's deception. As Anderson puts it, by "focalizing through a character who, intentionally or otherwise, mischaracterizes diegetic reality, the cinematic narrator can present a false version of the story" (2010: 89, emphasis added). Comparing The Sixth Sense and Stage Fright, both of which focalise through unreliable characters, Anderson (2010: 87), states that the former "misleads us-underreports events-while the latter lies to us-misreports events." Anderson (2010) maintains that in presenting the story through the skewed perspective of a character who misinterprets his/her experiences, as in The Sixth Sense, the multimodal narrator does not lie but deceives the viewer also through ambiguity. Similarly, Klecker claims that some mind-tricking films are based on "withholding information" but do not "actually lie in the sense of deliberately conveying information that is untrue. They leave strategically placed gaps that offer two possible interpretations-one during the first viewing and another (the final one) in retrospect, upon the disclosure of the surprise gap" (2013: 136, emphasis added).

It needs to be underscored that covert ambiguity and deceptively withholding information are two different forms of deception. Indeed, "underreporting", or rather withholding information through not revealing a basic fact about the protagonist in The Sixth Sense (i.e. that he is dead) invites covert ambiguity that underlies

\footnotetext{
${ }^{17}$ Anderson (2010: 89) claims that "in films that lie to or mislead the viewer, one character is almost always the explicit focalizer." However, deception performed by the cinematic narrator, which Anderson (2010) seems to have in mind, need not always be done though character focalisers, as evidenced by Example 1.
} 
the whole film in a garden-path manner (see Dynel, 2009). Essentially, the first part of a (here, multimodal) text must entail covert ambiguity, with only one meaning being effortlessly accessible to the hearer/recipient, and the second part of the text (the climax) must surprisingly invalidate the recipient's previous inference and prompt him/her to backtrack and reprocess the previous part of the text to appreciate an alternative, hitherto unobserved, meaning congruent with the meaning revealed in the climax. However, specific scenes may involve other deceptive strategies (e.g covert irrelevance, when the late man is talking to his wife, who is only doing self-talk).

This pattern based on withholding information and covert ambiguity underlies many films pivoted on multimodal deception that holds until the climax, not always involving character focalisation (cf. Examples 1 and 2). Whether or not filtering through one character, the tacit unreliable narrator, is deployed, the climax reveals the preceding ambiguity and prioritises an alternative, truthful reading on the entire film (e.g. a character is schizophrenic and has no friend, or a character wants to impress the crowd rather than committing suicide, etc.). What is important is that the specific scenes and phases throughout the film may deploy other forms of multimodal deception and cannot be reduced to the broadly understood covert ambiguity, as corroborated in the analyses in "Types of Multimodal Deception in Film". Different forms of deception addressed in language philosophy may be deployed jointly across modalities by the cinematic narrator, multimodal lies included (e.g. when a character is shown conversing with a person that later turns out to have been his hallucination rather than a real person inhabiting the fictional world, as in Fincher's Fight Club), to serve an overarching deceptive purpose that stems from the covert focalisation, which typically prevents the cinematic narrator from being held accountable for lying.

A remaining query is whether the flashback in Stage Fright does involve cinema narrator's lying when focalising through Johnny and his mendacious account, and whether this practice can be considered legitimate at all (see also Example 3). Indeed, this multimodal flashback is one of the scenes that "show us things that never occurred as if they had occurred; they can manifestly lie to the viewer about the diegetic world" (Anderson, 2010: 84). In this case, the cinematic narrator presents the diegetic world as filtered not through a confused or mentally incapacitated character (together with the lived experience, this seems to work as extenuating circumstances for the deceptive cinematic narrator, thus typically not considered to be lying) but, instead, through a character who is purposefully mendacious in his interaction with another character, offering a multimodal representation of his lies, and hence telling multimodal lies, which can be vindicated - it is argued here - by the embedded narration. The cinematic narrator's lying flashback gives the mendacious perspective of the character who acts as an intradiegetic narrator of the subordinate story. It is not the case that the intradiegetic narrator uses the cinematic narrator (Burgoyne, 1990) but vice versa, it is the cinematic narrator that uses the intradiegetic narrator and lends the latter support by rendering his narrative through a multimodal narrative in a flashback only to disclose the intradiegetic narrator's 
deception at the end of the film. ${ }^{18}$ This strategy seems to be considered controversial inasmuch as the ultimate reframing of the account as only a focalised fabricated version of events does not cancel or suspend the lies relative to the fictional world, which the other forms of reframing (e.g. as dreams or hallucinations) do, possibly even denying the status of assertions to the previous untruthful messages. ${ }^{19}$ Nonetheless, even if, intuitively, more controversial than the other forms of focalisation involving the character's genuine lived mental experience that make for untruthful multimodal statements (apart from using other forms of deception), the focalisation through a mendacious speaker who produces a false-believed narrative of "non-lived" experience can be regarded as being equally legitimate in cinematic narration.

All focalising situations may involve what later turns out to have been a sequence of untruthful multimodal messages and even assertions, and hence potential lies about the fictional world and its truth, retroactively reframed as belonging in a dream, illusion, delusion or, as is the case with Hitchcock's famous scene, as part of an intradiegetic narrator's mendacious account dramatised multimodally for the recipient's sake. Unlike in the case of deceptive focalisations through character minds' fabrications, the recipient is aware of the focalisation through a narrating character who performs verbal lies; it is the narrating character's mendacity that is covert, and so the retroactive reframing does not concern the very aspect of focalisation. In this case, the cinematic narrator reports the character's lies (and other deceptive utterances) to the recipient as if oblivious to the intradiegetic narrator's (un) truthfulness. In practice, through the cinematic narrator's focalising and later reframing of the multimodal lies, the collective sender aims to give the recipient a cognitive surprise, like through any other form of film deception targeted at the recipient (i.e. not revealed to the recipient at the moment of production).

It is hoped that this discussion disperses the doubt that critics instilled into Alfred Hitchcock: "Strangely enough, in movies, people never object if a man is shown telling a lie. And it's also acceptable, when a character tells a story about the past, for the flashback to show it as if it were taking place in the present. So why is it that we can't tell a lie through a flashback?" (Hitchcock in Truffaut, 1983: 189). As has been argued here, multimodal lies can be told through the cinematic narrator when (and only when) some form of character focalisation is used, whether the character is purposefully deceptive and his/her verbal lies are cinematically narrated as a multimodal lying flashback (the controversial case of non-lived experience) or has a warped view of the fictional world, is dreaming or purposefully imagining things (the widely accepted forms of the cinematic narrator's mendacity involving a tacit intradiegetic narrator and the representation of their lived experience). These are fine specimens of multimodal film deception targeted at the recipient.

\footnotetext{
${ }^{18}$ A statement may also be ventured that Hitchcock's film would not have stirred up so much controversy if the multimodal lies had been revealed to the recipient much sooner (cf. Example 3).

${ }^{19}$ The deception based on unannounced presenting a dream or hallucination through multimodal statements is similar to producing an utterance that is meant to be taken as a truthful assertion but is duly reframed as autotelic humour, whereby the non-assertoric nature of the statement is revealed (see Dynel, 2017, 2018). On an alternative account, this deception may then be considered to involve covert pretending to make an assertion rather than a mendacious assertion.
} 


\section{Conclusions and Final Comments}

This paper has given new insight into film deception in the context of relevant postulates made within the fields of film pragmatics and multimodality, the philosophy of fiction, including narrative theory, and the philosophy of deception. Deception in film can materialise through not only characters' verbalisations and non-verbal messages (i.e. signals, actions and artefacts), but also complex cinematic strategies. It has been shown that film is an elaborate multimodal artefact which can involve three main forms of film deception amenable to analysis also in the light of categories of deception (including lies) teased out by language philosophers, which can easily co-occur and be interdependent.

The fictional world constructed on screen can invite false make beliefs in viewers, as intended by the film production crew who use the cinematic narrator that reports on characters' interactions. The recipient is deceived by the production crew when he/she entertains false beliefs about what is the case in the fictional world at hand, typically without explicitly crediting the production crew (let alone the extradiegetic cinema narrator) for this.

Film deception may manifest itself on the characters' level of communication, being consequent upon fictional interactants' intradiegetic deception of one another (with the recipient being deceived or not) as shown on screen; and only on the recipient's level, which is when the recipient, but no fictional interactant, is deceived by the extradiegetic camera narrator, to whose presence the recipient remains oblivious when immersed in the fictional world. These two general forms of deception may co-occur, which is when the extradiegetic narrator offers a multimodal representation of an intradiegetic narrator's deceptive account. Each of the three types of film deception may materialise through any of the various types of (real-life) deception examined by philosophers (e.g. lying, deceptive implicature, withholding information, covert ambiguity or covert irrelevance). Contrary to popular opinion, multimodal lies are a legitimate, and by no means intermittent, cinematic strategy necessarily facilitated by focalising characters, who - typically - have a warped perception of the fictional world or who may be dreaming/imagining things (cf. their lived experience), but who may - more controversially - be narrating their mendacious accounts to other characters. Cinematic narrators thus reveal the deception by reframing the multimodal lies (and other deception) as being only a matter of individual mental experience rather than objective facts.

Importantly, the recipient must recognise the presence of film deception at some point for its designed effects to hold. Either viewers are privy to deception being performed by a character, or they must recognise a character's or the narrator's, and hence the film crew's, deception with the benefit of hindsight, whether in the same interaction, in a later one, or even at the very end of the film. Having been deluded, the recipient is invited to learn the truth in the fictional world, or more precisely what he/she make believes to be the truth in the fictional world (which, ideally, corresponds to what the production crew seem to regard as the fictional truth to be discovered by the recipient). The recipient's recognition of film deception necessitates world-repair or word-replacement in the incremental process of interpretation based on new incoming information (cf. Gavins, 2007). 
It is important to note that film deception is essentially performed for the sake of the recipient and should not be considered morally reprehensible. Viewers engaged in the act of watching a film develop false make beliefs, which do not carry any repercussions in the real world. This is why film deception and recognition thereof give the recipient cognitive pleasure rather than a sensation of being immorally fooled or taken advantage of, as is frequently the case with real-life deception.

\section{References}

Anderson, E. (2010). Telling stories: Unreliable discourse, Fight Club, and the cinematic narrator. Journal of Narrative Theory, 40(1), 80-107. https://doi.org/10.1353/jnt.0.0042.

Aquinas, T. (1972). Question 110: Lying. In Summa theologiae, Volume 41: Virtues of justice in the human community. New York, NY: McGraw-Hill.

Augustine. (1952). Lying. In R. J. Deferrari (Ed.), Treatises on various subjects (pp. 53-120). New York, NY: Catholic University of America.

Badura, C., \& Berto, F. (2018). Truth in fiction, impossible worlds, and belief revision. Australasian Journal of Philosophy, 97(1), 178-193. https://doi.org/10.1080/00048402.2018.1435698.

Bal, M. (1997 [1992]). Narratology. In Introduction to the theory of narrative. Toronto, Canada: University of Toronto Press.

Baldry, A., \& Thibault, P. J. (2006). Multimodal transcription and text analysis. London, UK: Equinox.

Banfield, A. (1978). Where epistemology, style and grammar meet: The development of represented speech and thought. New Literary History, 9(3), 415-445. https://doi. org/10.2307/468449.

Bateman, J., \& Schmidt, K.-H. (2011). Multimodal film analysis: How films mean. London, UK: Routledge.

Black, D. A. (1986). Genette and film: Narrative level in the fiction cinema. Wide Angle, 8(3/4), 19-26.

Bok, S. (1978). Lying: Moral choice in public and private life. New York, NY: Random House.

Booth, W. C. (1983 [1961]). The rhetoric of fiction. Chicago, IL: University of Chicago Press.

Bordwell, D. (1985). Narration in the fiction film. Madison, WI: University of Wisconsin Press.

Bordwell, D. (1989). Making meaning. Inference and rhetoric in the interpretation of cinema. Cambridge, MA: Harvard University Press.

Bordwell, D. (2008). Poetics of cinema. New York, NY: Routledge.

Bordwell, D., \& Thompson, K. (2013 [1979]). Film art: An introduction. New York, NY: McGraw-Hill.

Branigan, E. (1984). Point of view in the cinema: A theory of narration and subjectivity in classical film. Berlin, Germany/New York, NY: Mouton.

Branigan, E. (2013). Narrative comprehension and film. London, UK: Routledge.

Bubel, C. (2008). Film audiences as overhearers. Journal of Pragmatics, 40, 55-71. https://doi. org/10.1016/j.pragma.2007.10.001.

Burgoyne, R. (1990). The cinematic narrator: The logic and pragmatics of impersonal narration. Journal of Film and Video, 42, 3-16.

Carson, T. L. (2010). Lying and deception: Theory and practice. Oxford, UK: Oxford University Press.

Casetti, F. (1986). Antonioni and Hitchcock: Two strategies of narrative investment. SubStance, 51, 69-86. https://doi.org/10.2307/3684715.

Chatman. (1986). Review of narration in the fiction film. Wide Angle, 8(3), 139-141.

Chatman, S. (1978). Story and discourse. Ithaca, NY: Cornell University Press.

Chatman, S. (1990). Coming to terms: The rhetoric of narrative in fiction and film. Ithaca, NY: Cornell University Press. 
Chisholm, R., \& Feehan, T. (1977). The intent to deceive. The Journal of Philosophy, 74, 143-159. https://doi.org/10.2307/2025605.

Clark, H. (1996). Using language. Cambridge, UK: Cambridge University Press.

Clark, H., \& Van Der Wege, M. (2001). Imagination in discourse. In D. Schiffrin, D. Tannen, \& H. E. Hamilton (Eds.), The handbook of discourse analysis (pp. 772-786). Oxford, UK: Blackwell.

Cohn, D. (2000). Discordant narration. Style, 34, 307-316.

Currie, G. (1990). The nature of fiction. Cambridge, UK/New York, NY: Cambridge University Press.

Currie, G. (1995). Unreliability refigured: Narrative in literature and film. The Journal of Aesthetics and Art Criticism, 53, 19-29. https://doi.org/10.2307/431733.

Currie, G. (2004). Arts and minds. Oxford, UK: Oxford University Press.

Currie, G., \& Ichino, A. (2013). Imagination and make-believe. In B. Gaut (Ed.), The Routledge companion to aesthetics (pp. 320-329). London, UK: Routledge.

Daugherty, J. (2007). Narrative discourse revisited: A synopsis of Gérard Genette's Nouveau Discours du Récit. Journal of Literary Studies, 1, 59-66. https://doi. org/10.1080/02564718508529753.

DePaulo, B. (2010). Deception: It's what Dexter does best (well, second best). In B. DePaulo (Ed.), The psychology of Dexter (pp. 65-78). Dallas, TX: BenBella Books.

Doležel, L. (1980). Truth and authenticity in narrative. Poetics Today, 1, 7-26. https://doi. org/10.2307/1772407.

Doležel, L. (1998). Heterocosmica. Fiction and possible worlds. Baltimore, MD: Johns Hopkins University Press.

Dynel, M. (2019). To say the least: Where deceptively withholding information ends and lying begins. Topics in Cognitive Science, 1-28. https://doi.org/10.1111/tops.12379

Dynel, M. (2009). Humorous garden-paths: A pragmatic-cognitive study. Newcastle, UK: Cambridge Scholars Publishing.

Dynel, M. (2011a). "You talking to me?" The viewer as a ratified listener to film discourse. Journal of Pragmatics, 43, 1628-1644. https://doi.org/10.1016/j.pragma.2010.11.016.

Dynel, M. (2011b). Stranger than fiction. A few methodological notes on linguistic research in film discourse. Brno Studies in English, 37(1), 41-61.

Dynel, M. (2013). Humorous phenomena in dramatic discourse. The European Journal of Humor Research, 1, 22-60.

Dynel, M. (2016). Killing two birds with one deceit: Deception in multi-party interactions. International Review of Pragmatics, 8, 179-218. https://doi.org/10.1163/18773109-00802002.

Dynel, M. (2017). But seriously: On conversational humour and (un)truthfulness. Lingua, 197, 83-102. https://doi.org/10.1016/j.lingua.2017.05.004.

Dynel, M. (2018). Irony, deception and humour: Seeking the truth about overt and covert untruthfulness. Mouton series in pragmatics. Berlin, Germany: Mouton de Gruyter.

Ekman, P. (1985). Telling lies: Clues to deceit in the marketplace, politics, and marriage. New York, NY: Norton \& Company.

Elleström, L. (Ed.). (2010). Media borders, multimodality and intermediality. Basingstoke, UK: Palgrave Macmillan.

Elsaesser, T. (2009). The mind-game film. In W. Buckland (Ed.), Puzzle films. Complex storytelling in contemporary cinema (pp. 13-41). London, UK: Wiley-Blackwell.

Fallis, D. (2010). Lying and deception. Philosophers' Imprint, 10, 1-22.

Ferenz, V. (2008). Don't believe his lies: The unreliable narrator in contemporary American cinema. Trier, Germany: Wissenschaftlicher Verlag Trier.

Fink, G. (1982). From showing to telling: Off-screen narration in the American cinema. Littérature d'América, 3(12), 5-37.

Fludernik, M. (1999). Defining (in)sanity: The narrator of The Yellow Wallpaper and the question of unreliability. In W. Grunzweig \& A. Solbach (Eds.), Grenzüberschreitungen: Narratologie im Kontext/Transcending boundaries: Narratology in context (pp. 75-95). Tübingen, Germany: Narr. 
Forceville, C. (2010). The Routledge Handbook of Multimodal Analysis: Carey Jewitt (Ed.), Routledge, London, 2009, 340 pages, ISBN 13: 978-0-415-43437-9 (hbk). Journal of Pragmatics, 42:2604-2608. https://doi.org/10.1016/j.pragma.2010.03.003.

Forceville, C. (2002). The conspiracy in The comfort of strangers: Narration in the novel and the film. Language and Literature, 11, 131-147. https://doi.org/10.1177/0963947002011002883.

Forceville, C. (2007). Multimodal Transcription and Text Analysis: A Multimedia Toolkit and Coursebook: Anthony Baldry, Paul J. Thibault, Equinox, London/Oakville, 2006, 270 pp., \$40/£24.99 (paperback), ISBN 1-904768-07-5. Journal of Pragmatics, 39(6), 1235-1238. https://doi.org/10.1016/j.pragma.2007.02.007.

Friend, S. (2017). The real foundation of fictional worlds. Australasian Journal of Philosophy, 95, 29-42. https://doi.org/10.1080/00048402.2016.1149736.

Gaudreault, A. (1987). Narration and monstration in the cinema. Journal of Film and Video, 39, $29-36$.

Gavins, J. (2007). Text world theory: An introduction. Edinburgh, UK: Edinburgh University Press.

Genette, G. (1980 [1972]). Narrative discourse: An essay in method. Ithaca, NY: Cornell University Press.

Gerrig, R. (1993). Experiencing narrative worlds: On the psychological activities of reading. New Heaven, CT: Yale University Press.

Green, M., \& Brock, T. (2000). The role of transportation in the persuasiveness of public narratives. Journal of Personality and Social Psychology, 79, 701-721. https://doi. org/10.1037/0022-3514.79.5.701.

Green, M., \& Brock, T. (2002). In the mind's eye: Transportation-imagery model of narrative persuasion. In M. C. Green, J. J. Strange, \& T. C. Brock (Eds.), Narrative impact: Social and cognitive foundations (pp. 315-341). Mahwah, NJ: Lawrence Erlbaum.

Green, S. P. (2001). Lying, misleading, and falsely denying: How moral concepts inform the law of perjury, fraud, and false statements. Hastings Law Journal, 53, 157-212.

Grice, H. P. (1989). Studies in the way of words. Cambridge, MA: Harvard University Press.

Hamburger, K. (1957). Die Logik der Dichtung. In M. J. Rose (Ed.), The logic of literature, trans. Bloomington, IN: Indiana University Press.

Heyd, T. (2011). Unreliability. The pragmatic perspective revisited. Journal of Literary Theory, 5(1), 3-17. https://doi.org/10.1515/jlt.2011.003.

Janney, R. (2012). Pragmatics and cinematic discourse. Lodz Papers in Pragmatics, 8, 85-113. https://doi.org/10.1515/lpp-2012-0006.

Jewitt, C. (Ed.). (2009). The routledge handbook of multimodal analysis. London, UK: Routledge.

Klecker, C. (2013). Mind-tricking narratives: Between classical and art-cinema narration. Poetics Today, 34, 119-146. https://doi.org/10.1215/03335372-1894469.

Koch, J. (2011). Unreliable and discordant film narration. Journal of Literary Theory, 5(1), 57-80. https://doi.org/10.1515/jlt.2011.006.

Köppe, T., \& Kindt, T. (2011). Unreliable narration with a narrator and without. Journal of Literary Theory, 5, 81-94. https://doi.org/10.1515/jlt.2011.007.

Kozloff, S. (1988). Invisible storytellers. Berkeley, CA: University of California Press.

Kozloff, S. (2000). Overhearing film dialogue. Berkeley, CA: University of California Press.

Kress, G. (2010). Multimodality: A social semiotic approach to contemporary communication. London, UK: Routledge.

Kupfer, J. (1982). The moral presumption against lying. Review of Metaphysics, 36, 103-126.

Laass, E. (2008). Broken taboos, subjective truths: Forms and functions of unreliable narration in contemporary American cinema. A contribution to film narratology. Trier, Germany: Wissenschaftlicher Verlag Trier.

Lamarque, P. (1996). Fictional points of view. Ithaca, NY/London, UK: Cornell University Press.

Lewis, D. (1978). Truth in fiction. American Philosophical Quarterly, 15(1), 37-46.

Linsky, L. (1963). Deception. Inquiry, 6, 157-169. https://doi.org/10.1080/00201746308601371.

Lothe, J. (2000). Narrative in fiction and film: An introduction. Oxford, UK: Oxford University Press.

Mahon, J. E. (2015). The definition of lying and deception. In E. N. Zalta (Ed.), The Stanford encyclopedia of philosophy (Fall 2015 Edition). http://plato.stanford.edu/archives/fall2015/entries/ lying-definition/. 
Mahon, J. E. (2007). A definition of deceiving. International Journal of Applied Philosophy, 21, 181-194. https://doi.org/10.5840/ijap20072124.

Margolin, U. (1992). The nature and functioning of fiction: Some recent views. Canadian Review of Comparative Literature, 19, 101-117.

Martinec, R. (1998). Cohesion in action. Semiotica, 120(1-2), 161-180. https://doi.org/10.1515/ semi.1998.120.1-2.161.

Meibauer, J. (2005). Lying and falsely implicating. Journal of Pragmatics, 37, 1373-1399. https:// doi.org/10.1016/j.pragma.2004.12.007.

Meibauer, J. (2014). Lying and the semantics-pragmatics interface. Boston, MA/Berlin, Germany: Mouton de Gruyter.

Messerli, T. C. (2017). Participation structure in fictional discourse: Authors, scriptwriters, audiences and characters. In M. A. Locher \& A. H. Jucker (Eds.), Pragmatics of fiction. Handbooks of pragmatics (pp. 25-54). Berlin, Germany: Mouton de Gruyter.

Metz, C. (1974). Film language: A semiotics of the cinema. New York, NY: Oxford University Press.

Morley, D. (1980). The nationwide audience: Structure and decoding. London, UK: British Film Institute.

Murphet, J. (2005). Stories and plots. In H. Fulton, R. Huisman, J. Murphet \& A. Dunn (Eds.,) Narrative and media (pp. 47-59). New York, NY: Cambridge University Press.

Nichols, S., \& Stich, S. (2003). Mindreading. An integrated account of pretence, self-awareness, and understanding other minds. Oxford, UK: Oxford University Press.

Nünning, A. (2005). Reconceptualizing unreliable narration: Synthesizing cognitive and rhetorical approaches. In J. Phelan \& P. J. Rabinowitz (Eds.), A companion to narrative theory (pp. 89-107). Oxford, UK: Blackwell.

Nünning, V. (2015). Unreliable narration and trustworthiness. Intermedial and interdisciplinary perspectives. Berlin, Germany: De Gruyter.

Olson, G. (2003). Reconsidering unreliability: Fallible and untrustworthy narrators. Narrative, 11, 93-109.

Persson, P. (2003). Understanding cinema: A psychological theory of moving imagery. Cambridge, UK: Cambridge University Press.

Phelan, J. (2005). Living to tell about it. Ithaca, NY: Cornell UP.

Phillips, P. (2000). Understanding film text: Meaning and experience. London, UK: Bloomsbury.

Piazza, R., Bednarek, M., \& Rossi, F. (2011). Introduction: Analysing telecinematic discourse. In R. Piazza, M. Bednarek, \& F. Rossi (Eds.), Telecinematic discourse: Approaches to the language of films and television series (pp. 1-17). Amsterdam, Netherlands/Philadelphia, PA: John Benjamins.

Prince, G. (1987). A dictionary of narratology. Lincoln, NE: University of Nebraska Press.

Ronen, R. (1994). Possible worlds in literary theory. Cambridge, UK: Cambridge University Press.

Ryan, M.-L. (1980). Fiction, non-factuals, and the principle of minimal departure. Poetics, 9, 403-422.

Ryan, M.-L. (1981). The pragmatics of personal and impersonal narration. Poetics, 10, 517-539.

Ryan, M.-L. (1991). Possible worlds, artificial intelligence and narrative theory. Bloomington, IN: Indiana University Press.

Ryan, M.-L. (2001). Narrative as virtual reality: Immersion and interactivity in literature and electronic media. Baltimore, MD: Johns Hopkins University Press.

Ryan, M.-L. (2007). Toward a definition of narrative. In D. Herman (Ed.), The Cambridge companion to narrative (pp. 22-35). Cambridge, UK: Cambridge University Press.

Sainsbury, M. (2009). Fiction and fictionalism. London, UK: Routledge.

Shen, D. (2011). Unreliability. In P. Hühn et al. (Eds.), The living handbook of narratology. Hamburg, Germany: Hamburg University Press.

Siegler, F. (1966). Lying. American Philosophical Quarterly, 3, 128-136.

Simpson, D. (1992). Lying, liars and language. Philosophy and Phenomenological Research, 52, 623-639. https://doi.org/10.2307/2108211.

Smith, D. L. (2004). Why we lie: The evolutionary roots of deception and the unconscious mind. New York, NY: St. Martin's Press. 
Sorlin, S. (2016). Language and manipulation in House of Cards: A pragma-stylistic perspective. London, UK: Palgrave Macmillan.

Stafford, R. (2007). Understanding audiences and the film industry. London, UK: British Film Institute.

Stam, R., Burgoyne, R., \& Flitterman-Lewis, S. (1992). New vocabularies in film semiotics: Structuralism, post-structuralism and beyond. London, UK/New York, NY: Routledge.

Sternberg, M., \& Yacobi, T. (2015). (Un)reliability in narrative discourse: A comprehensive overview. Poetics Today, 36(4), 327-498. https://doi.org/10.1215/03335372-3455114.

Stühring, J. (2011). Unreliability, deception, and fictional facts. Journal of Literary Theory, 5, 95-107. https://doi.org/10.1515/jlt.2011.008.

Thompson, K. (1977). The duplicitous text: An analysis of Stage Fright. Film Reader, 2, 52-64.

Toolan, M. (2001[1988]). Narrative. A critical linguistic introduction. London, UK/New York, NY: Routledge.

Truffaut, F. (1983). Hitchcock/Truffaut. New York, NY: Touchstone.

Vincent Marrelli, J. (2004). Words in the way of truth. In Truthfulness, deception, lying across cultures and disciplines. Napoli, Italy: Edizione Scientifiche Italiane.

Vincent Marrelli, J. (2006). Truthfulness. In J. Verschueren, J.-O. Östman, J. Blommaert, \& C. Bulcaen (Eds.), Handbook of pragmatics (pp. 1-72). Amsterdam, Netherlands/Philadelphia, PA: John Benjamins.

Vrij, A. (2008). Detecting lies and deceit. Pitfalls and opportunities (2nd ed.). Chichester, UK: John Wiley.

Walton, Kendall. (1990). Mimesis as make-believe: On the foundations of the representational arts. Cambridge, MA: Harvard University Press.

Wharton, D., \& Grant, J. (2005). Teaching analysis of film language. London, UK: British Film Institute.

Wildfeuer, J. (2014). Film discourse interpretation. Towards a new paradigm for multimodal film analysis. London, UK/New York, NY: Routledge.

Zipfel, F. (2011). Unreliable narration and fictional truth. Journal of Literary Theory, 5(1), 109130. https://doi.org/10.1515/jlt.2011.009.

Open Access This chapter is licensed under the terms of the Creative Commons Attribution 4.0 International License (http://creativecommons.org/licenses/by/4.0/), which permits use, sharing, adaptation, distribution and reproduction in any medium or format, as long as you give appropriate credit to the original author(s) and the source, provide a link to the Creative Commons license and indicate if changes were made.

The images or other third party material in this chapter are included in the chapter's Creative Commons license, unless indicated otherwise in a credit line to the material. If material is not included in the chapter's Creative Commons license and your intended use is not permitted by statutory regulation or exceeds the permitted use, you will need to obtain permission directly from the copyright holder.

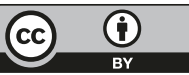

